\title{
Origin of the active drumlin field at Múlajökull, Iceland: new insights from till shear and consolidation patterns
}

Reba G. McCracken ${ }^{\mathrm{a},{ }^{*}}$, Neal R. Iverson ${ }^{\mathrm{a}}$, Ívar Ö. Benediktsson ${ }^{\mathrm{b}}$, Anders Schomacker ${ }^{\mathrm{c}}$, Lucas K.

Zoet $^{\mathrm{a}, \mathrm{d}}$, Mark D. Johnson ${ }^{\mathrm{e}}$, Thomas S. Hooyer ${ }^{\mathrm{f}}$, Ólafur Ingólfsson ${ }^{\mathrm{b}, \mathrm{g}}$

${ }^{a}$ Department of Geological and Atmospheric Sciences, Iowa State University, 253 Science I, 2237 Osborn Drive,

Ames, Iowa 50011, USA

*reebs.mccracken@gmail.com

${ }^{b}$ Institute of Earth Sciences, University of Iceland, Askja, Sturlugata 7, IS-101 Reykjavík, Iceland

${ }^{c}$ Department of Geology, UiT The Arctic University of Norway, Postboks 6050 Langnes, N-9037 Troms $\phi$, Norway

${ }^{d}$ Department of Geoscience, University of Wisconsin-Madison, Weeks Hall, 1215 West Dayton Street, Madison, WI

53715, USA

${ }^{e}$ Department of Earth Sciences, University of Gothenburg, Box 46, S-405 30 Göteborg, Sweden

${ }^{f}$ Department of Geosciences, University of Wisconsin-Milwaukee, P.O. Box 413, Milwaukee, WI 53201, USA

${ }^{g}$ The University Centre in Svalbard (UNIS), P.O. Box 156, N-9171 Longyearbyen, Norway

(C) 2016. This manuscript version is made available under the Elsevier user license http://www.elsevier.com/open-access/userlicense/1.0/ 


\section{ABSTRACT}

Stratigraphic and morphologic data previously collected from the forefield of Múlajökull, Iceland, suggest that its recent surge cycles are responsible for the formation of drumlins there and that their relief reflects both deposition on drumlins and erosion between them. We have tested these ideas and aspects of leading models of drumlin formation by studying past patterns of bed deformation and effective stress in basal tills of the glacier's forefield.

Patterns of till strain indicated by the anisotropy of magnetic susceptibility (AMS) of 2300 intact till samples indicate that till was deposited during shear deformation, with shearing azimuths and planes that conform to the drumlin morphology. Thus, till deposition occurred as drumlins grew, in agreement with LiDAR data indicating that the degree of aggradation of the glacier forefield is largest in areas subjected to the most surges. Previously described unconformities on the drumlin flanks, however, indicate that drumlin relief at Múlajökull has resulted, in part, from erosion. Given that the last surge deposited a till layer both on and between drumlins, a reasonable hypothesis is that erosion between drumlins occurred during normal (quiescent) flow of the glacier between surges. Densities of till samples, analyzed in conjunction with laboratory consolidation tests, indicate that effective stresses on the bed during such periods were on the order of $100 \mathrm{kPa}$ larger between drumlins than within them, an observation consistent with subglacial channels at low water pressure occupying interdrumlin areas. Transport of sediment by turbulent flow in these channels or high effective stress adjacent to them causing enhanced till entrainment in ice or increased depths of bed deformation would promote the sediment flux divergence necessary to erode areas between drumlins. The observation that effective stresses were higher between drumlins than within them is the opposite of that presumed in leading models of drumlin formation. Moreover, the lack of AMS-fabric 
evidence of longitudinal compression in drumlin tills does not support some models of drumlin formation that invoke negative till-flux gradients in a deforming bed.

KEYWORDS: glacier, drumlin, Múlajökull, till, fabric, consolidation

\section{INTRODUCTION}

Bedforms of former ice sheets are ubiquitous in the Northern Hemisphere, covering vast areas of Canada ( 70\% of the total land area), Ireland ( 50\%), Scandinavia ( 40\%), and Britain ( 15\%) (Clark et al., 2009). They have also been observed adjacent to and beneath the Antarctic Ice Sheet (Ó Cofaigh, 2002; King et al., 2007). These bedforms are the result of subglacial processes that are difficult to observe directly, despite advances in remote-sensing, borehole, and seismic technology and the establishment of subglacial laboratories that make glacier beds more accessible (Clarke, 2005). This poor capacity for direct observation results in an understanding of glacial bedforms that is primitive relative to that of, for example, fluvial bedforms, which are far more easily related to the properties of the flows that make them and adjust to them (e.g., Allen, 1985). A similarly advanced understanding of glacial bedforms would not only help resolve longstanding questions regarding their origins but would help reveal their effects on the slip dynamics of modern (e.g., King et al., 2009) and past soft-bedded ice masses (e.g., Boulton, 1996).

Achieving that level of understanding of drumlins, although difficult, would be particularly significant, given the substantial attention that they have received (Clark et al., 2009) and the lack of a complete, empirically defensible explanation for their formation. Several theories of 
drumlin formation, with varying degrees of empirical justification and mathematical formalism, have been offered (e.g., Menzies, 1979; Boulton, 1987; Hindmarsh, 1998; Fowler, 2010; Hooke and Medford, 2013; Fowler and Chapwanya, 2014; Eyles et al., 2016). However, none of these theories is grounded on a coherent set of observations from a drumlin field shaped by—and still being shaped by-a modern glacier.

Thus, the philosophy that guides this study is that we potentially can learn something new and valuable from a modern case study — in this case, from the active drumlin field in the forefield of the Icelandic surge-type glacier, Múlajökull (Figs. 1 and 2). Since the field was first described (Johnson et al., 2010), 143 drumlins have been identified there (Benediktsson et al., 2016), and at least five new drumlins have emerged from beneath the receding glacier margin. Knowledge of the glacier's recent surge history and of the morphology and stratigraphy of the drumlins in its forefield (Johnson et al., 2010; Jónsson et al., 2014; Sigurkarlsson, 2015; Benediktsson et al., 2016) provides a foundation for this study. Principal interpretations of those data, discussed subsequently, are that drumlins have been progressively shaped during recent surge cycles, that they have grown through a combination of erosion and deposition of till, and that their relief may have been increased by feedbacks associated with crevasse swarms on the glacier surface coincident with underlying drumlins.

The aim of this study was to test these ideas and aspects of more formal models of drumlin formation (Boulton, 1987; Fowler and Chapwanya, 2014) by collecting new data relevant to subglacial kinematics and stresses. To this end, we have analyzed 81 fabrics based on the anisotropy of magnetic susceptibility (AMS) of 2328 intact till samples collected from drumlins 
and interdrumlin areas and have interpreted these fabrics together with till clast fabrics from previous studies (Johnson et al., 2010; Benediktsson et al., 2016) and new clast-fabric data. Importantly, we have also made more than 2000 measurements of till density from drumlins and interdrumlin areas, which we interpret in the context of laboratory consolidation tests. AMSbased fabrics, interpreted using results of laboratory ring-shear experiments on the Múlajökull till, provide information on flow patterns at the bed and the state of strain associated with till deposition. Till clast fabrics are used to help corroborate aspects of the AMS fabrics. The till density data provide patterns of past effective stress on the bed-a control variable in most models of drumlin formation that has not been previously measured for both drumlins and intervening swales. Ancillary results include azimuths of striations on bullet boulders on drumlins, to provide basal sliding patterns, and flow-parallel elevation profiles of the glacier forefield based on LiDAR data, to help assess net sedimentation that has accompanied drumlinization. We begin by briefly summarizing some leading models of drumlin formation and highlighting their predictions of patterns of strain in the bed and of basal effective stress. To avoid a lengthy summary of the voluminous literature on drumlins, we refer readers to reviews by Clark (2010) and Stokes et al. (2011).

\section{HYPOTHESES FOR DRUMLIN FORMATION}

Some hypotheses can be readily excluded for the drumlins of Múlajökull. For example, those that rely on a partly frozen bed (Hooke and Medford, 2013) cannot be tested because Múlajökull is a fully warm-based glacier (Björnsson et al., 2003). Similarly, deposition of drumlins by subglacial water (e.g. Shaw, 1983; McCabe and Dardis, 1989) is not considered further because the drumlins of Múlajökull consist almost entirely of till (Johnson, et al., 2010). 
We focus on two particularly widely cited models that deserve serious consideration for the drumlins of Múlajökull. In both models, bed deformation is assumed to be the dominant mechanism of sediment transport. In one case, geologic and associated hydrologic heterogeneity in the bed results in feedbacks that cause drumlin growth (Boulton, 1987). In the other case, drumlins grow due to a shear instability at the ice-till interface and the action of water in intervening swales (Fowler, 2010; Fowler and Chapwanya, 2014). In both cases, drumlins can grow as a result of a combination of deposition on them and erosion between them.

\subsection{Drumlin formation due to bed heterogeneity}

As glaciers override sediments with a range of textures and hence permeabilities, pore-water pressures - and thus effective stresses within the bed — necessarily vary spatially. Changes in texture, for example within a given till unit, can produce permeability gradients that could cause significant gradients in effective stress (e.g., Piotrowski and Tulaczyk, 1999; Knight, 2014). Subglacial sediment in zones where effective stresses are relatively high will be more consolidated and thus stronger than adjacent sediment under less effective stress. These pockets of strong sediment will form the rigid or more slowly deforming cores that may nucleate drumlins (Boulton, 1987). As ice flows over these cores, adjacent weaker sediments deform around them. Net positive sediment flux divergence occurs between the cores, and these regions become low-elevation interdrumlin areas. On and downstream from the crests of drumlins, till is deposited, also creating relief, and till shearing creates progressively more streamlined forms. In the numerical model used to develop this hypothesis, till is assumed to be incompressible and linear-viscous at stresses above its yield strength, and hydrologic heterogeneities are specified by 
varying sediment viscosity and effective normal stress. Although subglacial till is neither incompressible nor linearly-viscous (Kamb, 1991; Iverson et al., 1998; Tulaczyk et al., 2000), the central role of effective-stress heterogeneity linked to geologic heterogeneity and its effect on sediment mobility make this model intuitively appealing.

Tills in drumlins formed in this way would include fabrics that reflect simple shear, with shearing azimuths that conform to the drumlin shape. In addition, fabrics at drumlin heads and tails might show signs of longitudinal compression and extension, respectively. The sediment of the rigid cores may or may not have been deformed and would have been under the highest effective stresses, with lowest effective stresses on the sediments of interdrumlin areas, where porewater pressures would be highest.

\subsection{Subglacial landforms resulting from shear instability at the ice-bed interface}

A set of closely related, more formal hypotheses relies on an interfacial shear instability at the ice-bed contact to form transverse ridges (e.g., Hindmarsh, 1998; Hindmarsh, 1999; Schoof, 2007; Fowler, 2009). As these ridges form, they are sculpted into drumlins as the till bed is squeezed toward incipient low areas between drumlins where water layers accumulate and carry the sediment downglacier (Fowler and Chapwanya, 2014). Fundamental to the ridge-forming instability is that ice flow over a bump on the bed causes compressive normal stresses that peak on the stoss surface and are minimized on the lee surface. If the assumptions are made that (1) till has a viscosity that increases with effective normal stress, (2) till flux increases with increasing bed shear stress, and (3) till shearing resistance is much less than that of ice, so that ice velocity at the bed surface is uniform across the bump, then the flux of till by bed 
deformation on stoss surfaces will exceed that on lee surfaces, and the bump will grow into a transverse ridge. The formation of three-dimensional, flow-parallel hills (drumlins) as these ridges grow arises from local zones of erosion of till along ridge crests. Erosion in these areas is dictated by the tendency of subglacial water to pool and cause ice-bed decoupling in incipient interdrumlin areas. Effective normal stress exerted by the ice on the bed surface in these areas is considered to be zero, and till is squeezed into the pooling water and evacuated by it as it flows downglacier (Fowler, 2010). The first two of the assumptions necessary for the ridge-growth instability are heuristic and not supported by either experiments on till (see Iverson, 2010, for a review) or traditional models from soil mechanics (e.g., Lambe and Whitman, 1979). Nevertheless, this family of models has appeal because hills arise naturally from bed deformation and because it can explain a spectrum of subglacial bedforms (Fowler and Chapwanya, 2014).

The net flow of till into incipient transverse ridges will result in till fabrics that reflect longitudinally-compressive strain. This strain regime would characterize drumlins formed by deposition of unconformable layers on top of preexisting sediments. Preexisting sediments would have fabrics that would not necessarily correspond with the drumlin form. The lateral sediment transport in a deforming bed required for drumlinization of the ridges would lead to fabrics indicative of either lateral extension or lateral shear away from drumlin long axes. Till on the stoss sides of the ridges will have experienced higher effective stresses than till in their lees, with interdrumlin areas subject to the low (approaching zero) effective stresses thought to be associated with the subglacial water layer. 


\section{SETTING AND BACKGROUND}

Most of the studies that have informed existing hypotheses for drumlin formation have focused on drumlins formed by Pleistocene ice sheets (Clark et al., 2009). Although individual contemporary drumlins have been identified in Iceland (Boulton, 1987; Krüger, 1987;

Schomacker et al., 2006), Switzerland (van der Meer, 1983), Alaska (Haselton, 1966), and Antarctica (Rabassa, 1987), no active drumlin fields were known to exist in modern glacier forefields until Johnson et al. (2010) described the drumlin field at Múlajökull, Iceland.

\subsection{Múlajökull surge history}

Múlajökull is a soft-bedded glacier that drains the Hofsjökull Ice Cap in central Iceland (Minchew et al., 2016). The glacier flows through a $2 \mathrm{~km}$-wide valley, before spilling out onto an unconfined plain to form a $\sim 4$ km-wide, highly crevassed piedmont lobe (Jónsson et al., 2014). Previous interest in Múlajökull has centered on its surge history (e.g., Björnsson et al., 2003). Since 1945, it has surged six times, with four major advances of the margin (>150 m) that repeatedly overrode the same $0.4-1.3 \mathrm{~km}^{2}$ section of the forefield (Fig. 1) (Sigurkarlsson, 2015; Benediktsson et al., 2016). The most distal moraine in the forefield was deposited in the first half of the 1700s (the Little Ice Age), during the glacier's maximum surge (Benediktsson et al., 2015). After its last major surge in 1992 , the glacier began retreating relatively consistently at an average rate of $\sim 45 \mathrm{~m} \mathrm{a}^{-1}$ and has experienced only one minor surge advance since then, in 2008 (Johnson et al., 2010). This surge deposited a narrow, ice-cored, hummocky end moraine (Fig. 2). "Quiescent periods" (Cuffey and Paterson, 2010) between surges have averaged about 12 years, with a standard deviation of 5.4 years, since the 1952 surge. Airborne interferometric synthetic aperture radar data collected in 2013-2014 indicate that during the current quiescent 
period the glacier moves $\sim 30 \mathrm{~m} \mathrm{a}^{-1}$ at a distance $\sim 1 \mathrm{~km}$ from the glacier margin (Minchew et al., 2016). Glacier flow during quiescent periods, as has commonly been observed elsewhere (Cuffey and Paterson, 2010), is hereinafter referred to as "quiescent flow." During the current quiescent period, portals draining water from beneath the glacier are located in areas primarily between drumlins. However, no data from Múlajökull exist on the subglacial hydrological changes there that likely initiated surges (e.g., Kamb et al., 1985; Cuffey and Paterson, 2010).

\subsection{The Múlajökull forefield and drumlins}

The glacier forefield is an expansive plain composed primarily of subglacial till (up to seven till units have been identified, Benediktsson et al., 2016), which is drumlinized within $\sim 1 \mathrm{~km}$ of the glacier margin. Till from the various till units in the drumlins varies little in texture, with 0-13\% clay-, 36-53\% silt-, and 44-65\% sand-sized grains (Dillner, 2011). The 143 drumlins occur in a fan-like distribution (Fig. 1) — characteristic of many Pleistocene drumlin fields (Patterson and Hooke, 1995) - that mimics the curvature of the piedmont glacier margin (Johnson et al., 2010; Benediktsson et al., 2016). Jónsson et al. (2014) mapped the forefield and an initial 110 drumlins, and Benediktsson et al. (2016) mapped an additional 33 drumlins, confirming that the dimensions of the Múlajökull drumlins fall within the lower end of the range observed in Pleistocene drumlin fields (e.g., Clark et al., 2009). Two-thirds of these drumlins occur upglacier of the 1992 surge moraine (Benediktsson et al., 2016), which coincides with the glacier extent after at least three other recent surge events (Fig. 1) (Sigurkarlsson, 2015). Benediktsson et al. (2016) found that the drumlins that lie upglacier of the 1992 moraine have larger elongation ratios than those that lie downglacier of it and concluded that drumlin forms likely became more developed (i.e., streamlined) as they experienced more surge cycles or longer cumulative 
residence time beneath the ice. Researchers investigating Pleistocene drumlin fields also have made this suggestion (e.g., Boyce and Eyles, 1991; Briner, 2007; Clark et al., 2009).

Both Johnson et al. (2010) and Benediktsson et al. (2016) hypothesized that drumlin development at Múlajökull occurred through a combination of till deposition near drumlin crests and erosion along their heads and sides, based on stratigraphic observations. In particular, these authors noted that (1) after the 2008 surge, a new till unit was exposed between that surge's end moraine and the ice margin, both on and between drumlins, suggesting that the till unit was deposited during the 2008 advance (Benediktsson et al., 2016); (2) some older till units can be linked to surge moraines—including the moraine deposited by the 1992 surge-indicating that these till units were likely emplaced during surges (Johnson et al., 2010); (3) upper till units sometimes truncate underlying ones (Fig. 3) along drumlin flanks and in one case at a drumlin head, indicating that lower till units have sometimes been eroded before new ones have been emplaced (Johnson et al., 2010; Benediktsson et al., 2016); and (4) till units, described in four cross sections, tend to have strikes and dips conforming to the drumlin shape, which implies that the forefield was drumlinized prior to their deposition (Benediktsson et al., 2016).

Johnson et al. (2010, see their Fig. 4) first noted that crevasse swarms on the glacier, observed in air photos three years after the 1992 surge, were coincident with underlying drumlins that have subsequently been exposed by recession of the margin. They and Benediktsson et al. (2016) suggested that these crevasse swarms would have affected the stress distribution at the bed, thereby causing patterns of erosion and deposition that might have amplified drumlin relief. 


\section{METHODS}

\subsection{Elevation profiles}

To study trends in forefield surface elevation at scales larger than individual landforms and thereby make inferences about large-scale sedimentation patterns, elevation profiles of the forefield were extracted from a 2 m, LiDAR-based DEM, from 2013. Data collected from airborne LiDAR measurements in Iceland have a vertical resolution $<0.5 \mathrm{~m}$, as shown through comparison with ground-based differential GPS measurements (Jóhannesson et al., 2011). These profiles were measured perpendicular to the ice margin and grouped in swaths of 10 parallel profiles, spaced $10 \mathrm{~m}$ apart such that the swaths were $100 \mathrm{~m}$ wide and, wherepossible, included both drumlin and interdrumlin areas. An average profile was calculated for each swath by finding the average elevation of each of its 10 constituent profiles at a given distance from the glacier margin. We compared swath profiles from 10 locations across the forefield (Fig. 1) by referencing them to the location and elevation where they intersected the upglacier edge of the 1992 moraine (mapped by Jónsson et al., 2014).

\subsection{Fabric measurements}

\subsubsection{AMS fabrics}

Subjecting an intact rock or sediment sample to a magnetic field of strength $H$ results in an induced magnetic field of strength $M$, such that $M=k H$, where $k$ is the susceptibility constant (Tarling and Hrouda, 1993). Magnetic susceptibility is usually due to a small quantity $(<1 \%)$ of a combination of ferrimagnetic, paramagnetic, and diamagnetic mineral grains within the sample. The susceptibility constant $k$ can be characterized with a second-rank tensor and, when anisotropic, visualized using an ellipsoid with long, intermediate, and short axes proportional to 
the principal orientations of susceptibility, $k_{1}, k_{2}$, and $k_{3}$, respectively (Fig. 4). Geomagnetic analyses conducted by Ives (2016) indicate that the magnetic signature of the Múlajökull tills is dominated by pseudosingle-domain and multidomain titanomagnetite, with some titanomaghemite, with grains primarily of silt size (see Appendix A). The AMS of these minerals is controlled by the grain morphology, such that their principal-susceptibility axes align with the morphological axes of the grains (Tarling and Hrouda, 1993). Thus, the AMS of an intact sample of the Múlajökull tills represents a volume-average of the preferred orientations of elongate, siltsized, ferrimagnetic grains in that sample.

Fabrics based on the principal-susceptibility orientations of multiple till samples reliably indicate strain patterns for the case of simple shear (Hooyer et al., 2008; Iverson et al., 2008). These fabrics are characterized by their $V_{l}$ eigenvectors, or the orientation of maximum clustering of principal-susceptibility axes. The $S_{1}$ eigenvalues associated with each eigenvector-which can range from 0.33 , indicating a uniform distribution of orientations with zero clustering, to 1.00 , indicating perfect clustering at a single orientation (Mark, 1973) — can be used to quantify fabric strength, and more importantly for this study, $V_{l}$ eigenvectors provide information about strain orientation. Notably, unlike in rocks where the elongation or flattening of the AMS ellipsoid from a single specimen can provide information about strain (e.g., Borradaile and Jackson, 2004; Stevenson et al., 2007), ring-shear experiments on various tills demonstrate conclusively that the AMS of individual samples does not provide a reliable basis for inferring strain magnitude or orientations (Hooyer et al., 2008; Vreeland et al., 2015). Thus, in this study, inferences about strain are based only on fabrics computed from 25 or more intact till samples. 
Ring-shear studies of AMS fabric development in tills (see Iverson et al., 2008, for an overview) indicate that orientations of principal susceptibility cluster predictably in simple shear if shear strains are sufficiently large ( 7-10). The $V_{l}$ eigenvector of $k_{l}$ orientations usually plunges 15 $30^{\circ}$ upglacier and parallel to the shearing direction (Iverson et al., 2008). Particle rotation along Riedel shears likely explains this upglacier plunge (Thomason and Iverson, 2006). Typically, the $V_{1}$ eigenvector of $k_{2}$ orientations lies within the shear plane and perpendicular to the shearing direction, and $k_{3}$ orientations cluster perpendicular to $k_{1}$ and $k_{2}$ (Fig. 4a) (Iverson et al., 2008). Thus orientations of $k_{1}$ and $k_{2}$ define the attitude of the shear plane. A useful aspect of knowing the shear-plane attitude is that the $V_{l}$ eigenvector of $k_{l}$ orientations, which plunges predictably with respect to the shear plane as noted, can be projected onto the shear plane to determine the true shearing azimuth (Vreeland et al., 2015). Except for the case of shear planes with steep, transverse dip components, which are rare, this correction is small.

To study the relationship between the orientations of principal susceptibility and simple shear for tills of the Múlajökull forefield, till collected from Site 1 (Fig. 5) at a depth of $0.3 \mathrm{~m}$ was sheared in two experiments with a ring-shear device to strains ( 31 and 37) sufficient to develop a steady-state AMS fabric, and the resultant AMS fabrics based on 50-75 samples of the sheared till were measured. The procedure (Hooyer et al., 2008) and apparatus (Iverson et al., 1997) for these experiments have been described in detail elsewhere. Results of these laboratory studies provide a solid basis for inferring shearing direction and shear-plane orientations from triaxial AMS fabrics of the Múlajökull tills. 
Fabrics resulting from compressional strain can be inferred by considering the rotation of passive lines in a body as it is compressed in pure shear. As strain increases, orientations of $k_{3}$ should align with the most compressive principal stress, whereas $k_{1}$ and $k_{2}$ orientations should become increasingly normal to it (Fig. 3b) (e.g., Owens, 1974; Ankerstjerne et al., 2015). Thus, although the principal-susceptibility orientations that develop from simple shear form distinct clusters (Fig. 3a), only $k_{3}$ orientations cluster in fabrics that develop from compressional strain, and $k_{1}$ and $k_{2}$ orientations instead form a girdle. This distinctive pattern-observed in a detailed study of a moraine subjected to shortening in the direction of glacier flow (Ankerstjerne et al., 2015)_enables differentiation of fabrics of tills that have been subjected to dominantly pure shear from those that have been subjected to dominantly simple shear. Interpreting the different fabric patterns this way requires recognition that pure shear and simple shear are end members of a continuum and that, although strain resulting from simple shear can always be caused by suitably orientated pure shear (e.g., Hobbs et al., 1976), the geometry of the subglacial environment allows the dominant strain end member to be determined.

Intact till samples for AMS measurements were collected from $\sim 1.0 \mathrm{~m}$ x $0.5 \mathrm{~m}$ platforms at depths of 0.2-5.9 $\mathrm{m}$ in basal tills of eight drumlins and three interdrumlin areas (Fig. 5). These platforms were excavated at depths aimed at sampling as many separate basal till units as possible. In most cases, platform locations were chosen to take advantage of natural outcrops incised by streams, with pits dug horizontally into basal tills, after removing up to $\sim 0.5 \mathrm{~m}$ of colluvium from the exposure surface. In addition, five $\sim 1.0 \mathrm{~m}$ x $2.0 \mathrm{~m}$ trenches (three at drumlin heads and two in interdrumlin areas) were dug vertically to depths of $\sim 1.5 \mathrm{~m}$, with horizontal platforms established at various depths as the trenches were excavated. Each platform was 
cleared to create a level surface (Fig. 6a). Six fabrics (three total from interdrumlin Sites 18 and 19 and three from drumlin Site 21) were collected from $\sim 1.0 \mathrm{~m}$ x $0.2 \mathrm{~m}$ vertical surfaces, rather than horizontal surfaces (Fig. 6b). Each of these fabrics was confined to one till unit, visually assessed in the field, within a single stream cut exposure. AMS samples were collected from each surface by pressing open-ended, plastic, cubic boxes $(\sim 18 \mathrm{~mm}$ across the inside, with a wall thickness of $1 \mathrm{~mm}$ ) (Fig. 6) into the platforms or vertical faces, avoiding any sediment that was not in place, and then excavating and capping the filled boxes. Only the outermost $\sim 2 \mathrm{~mm}$ of the samples were likely disturbed by this process (Tarling and Hrouda, 1993, p. 70). A total of 81 fabrics, each derived from $\geq 25$ AMS samples, were measured across the forefield. These samples were analyzed using a KLY-3S Kappabridge operated within the University of Wisconsin-Milwaukee's Department of Geosciences.

In addition to considering AMS fabrics on a drumlin-by-drumlin basis, data from all of the sampled drumlins were evaluated collectively by reorienting the drumlins (arbitrarily to N-S) so that their long axes coincided. Drumlins were divided into quadrants defined by longitudinal and transverse transects through the drumlin peak, and collective fabric data were assessed for each quadrant. When the data were parsed in this manner, however, the number of fabrics in a quadrant was sufficiently low $(\mathrm{N}<20)$ that outliers could obfuscate overall trends. Performing a nonparametric bootstrap analysis, which uses Monte Carlo probability modelling to delineate confidence areas (Tarling and Hrouda, 1993), on the AMS fabric data provided a clearer representation of fabric variability. This technique has been commonly applied to magnetic data (e.g., Sierra et al., 1993; Butler et al., 2002; Domeier et al., 2011; Granot et al., 2011; Weil et al., 2014). Bootstrap analysis operates under the assumption that the sampled dataset is 
representative of the entire population. Nonparametric bootstrapping resamples the dataset thousands of times, without assuming a particular data distribution, to understand variability in the overall population distribution (Singh and Xie, 2008). We analyzed distributions of $V_{l}$ eigenvectors of triaxial AMS fabrics from each of the drumlin quadrants using the nonparametric bootstrap routine developed by Constable and Tauxe (1990). Further explanation of this method can be found in Efron (1982) or Efron and Tibshirani (1986).

\subsubsection{Clast fabrics}

Clast fabrics of this study were each based on the long-axis orientations of 25 pebble-sized ( $\sim 5$ to $60 \mathrm{~mm}$ ) clasts with an elongation ratio of at least 1.5. Clast orientations were measured from $\sim 0.4 \mathrm{~m}$ x $0.4 \mathrm{~m}$ vertical faces in four drumlins and two interdrumlin areas. Sampling sites were located at depths of 0.2 to $5.9 \mathrm{~m}$ in natural outcrops (stream cuts) that were cleared of up to $\sim 0.5$ $\mathrm{m}$ of colluvium to reveal intact basal tills. Clasts were carefully excavated from the vertical surface, and the trends and plunges of their long axes were measured. Resultant fabrics were analyzed in the same way as magnetic susceptibility orientations.

\subsection{Bullet boulder measurements}

To understand patterns of ice flow in the Múlajökull drumlin field, we measured the orientations of striations with visible relief on large $(\geq 0.25 \mathrm{~m})$ boulders with abraded stoss and plucked lee ends—-so called bullet boulders—on the surfaces of some drumlins sampled for fabric analysis. Such boulders develop their characteristic shape as the glacier flows over them while they are partly embedded in the till (Boulton, 1978; Krüger, 1984). Average striation orientations on a given boulder were assessed by measuring multiple striations or visually averaging orientations 
during measurements with a Brunton compass. Boulders that appeared to be displaced, usually by mass wasting or fluvial erosion, or that had two clear sets of striations at clearly different orientations were excluded.

\subsection{Consolidation and effective stress measurements}

The degree of till consolidation provides a record of the maximum effective stress (total normal stress on the bed minus pore-water pressure) that the till has experienced since deposition. We evaluated relative till consolidation across the forefield by drying and weighing the 2378 AMS boxes to determine the dry bulk density of the intact till samples contained within them. These boxes, by necessity, were pushed into zones of till matrix that were free of large grains, so

although each sample was small, it preferentially contained the till textural component with bulk density most sensitive to effective normal stress on the bed. Till texture, which can also affect bulk density, was measured using sieving and pipette analysis (USDA, Soil Survey Investigations Report No. 42, 2014).

We evaluated the compressibility of Múlajökull tills to estimate the differences in past maximum effective stress that measured bulk densities represent. We are most interested in past maximum effective stress, so we are concerned only with the "virgin compressibility" (Das, 2010) of the till, or how it consolidated when the applied stress exceeded any stress that the till had experienced previously. A till's virgin compressibility can be derived from the results of preconsolidation testing of intact till samples. We collected samples for this purpose from the horizontal AMS platforms at as many locations as possible by pushing brass rings $(20 \mathrm{~mm}$ thickness, $75 \mathrm{~mm}$ diameter) into the platform surfaces and carefully excavating them. We then 
stabilized them between two metal plates to avoid disturbance of the samples during transport and sealed them in plastic wrap to prevent drying and shrinkage prior to testing. In the laboratory, the intact till samples were saturated with deionized water and placed in a fixed-ring consolidometer. Then, the till sample was incrementally loaded every 24 hours and its onedimensional consolidation measured with a dial micrometer and characterized by changes in the void ratio $(e)$ of the till. The virgin compression curve, defining the relationship between an applied effective normal stress $\left(\sigma^{\prime}\right)$ and the corresponding value of $e$, is given by $e=e_{0}-$ $C_{c} \log \left(\frac{\sigma^{\prime}}{\sigma_{0}}\right)$, where $C_{c}$ is the compression index (a measure of the till's compressibility) and $e_{0}$ and $\sigma_{0}^{\prime}$ are reference values of initial void ratio and preconsolidation stress (e.g., Clarke, 1987). We developed a virgin compression curve for the Múlajökull tills using the results of five preconsolidation tests following a method described in Das (2010), in which $e_{0}$ and a value $60 \%$ less than that $\left(e_{0.4}\right)$ are plotted with their corresponding values of stress $\left(\sigma_{0}^{\prime}\right.$ and $\sigma_{0.4}^{\prime}$, respectively) to constrain the value of $C_{c}$. Knowing this value allows differences in void ratio and hence bulk density to be related to spatial variations in effective pressure.

\section{RESULTS}

\subsection{Elevation profiles}

LiDAR-based profiles of the glacier forefield (Fig. 1) indicate that elevations increase with proximity to the glacier margin (Fig. 7). In most $100 \mathrm{~m}$-wide, swath profiles, a sharp change in slope occurs in the vicinity of the 1992 surge moraine, with abrupt steepening downglacier from the moraine - with the average slope (-0.023) of the forefield downglacier of the 1992 moraine more than three times as steep as the average slope (-0.007) of the forefield upglacier of it. 


\subsection{Fabrics}

\subsubsection{Ring-shear experiments}

During ring-shear testing, the Múlajökull till developed fabric orientations consistent with previous ring-shear studies in which other tills were sheared (Iverson et al., 2008), with each of the principal susceptibilities $\left(k_{1}, k_{2}\right.$, and $\left.k_{3}\right)$ forming distinct clusters, the $V_{l}$ eigenvector of the $k_{1}$ orientations plunging $15-24^{\circ}$ upglacier from the shear plane, and the $V_{l}$ eigenvector of $k_{2}$ orientations lying within the shear plane (Fig. 8). Fabric strengths, based on the degree of clustering of $k_{1}$ orientations ( $S_{1}=0.74$ and $S_{1}=0.77$ ), were $12-25 \%$ lower than those measured in previous studies, despite experiments conducted to strains 3-5 times greater than the minimum value required to produce steady-state fabrics in other tills (Iverson et al., 2008).

\subsubsection{AMS and clast fabrics}

In each of the 81 AMS fabrics from the Múlajökull forefield, the orientations of the three principal susceptibilities were clustered (e.g., Fig. 9; additional figures are included in the online supplementary material); no girdled fabrics like those of Fig. 4b were observed. Fabric strengths ranged from very strong $\left(S_{1}=0.95\right)$ to weak $\left(S_{l}=0.44\right)$, although $80.2 \%$ of fabrics were sufficiently strong $\left(S_{l}>0.57\right)$ to have directional significance based on the criterion set by Vreeland et al. (2015) in their study of drumlins of the Green Bay lobe. The average fabric strength, based on the degree of clustering of $k_{l}$ orientations, was $S_{l}=0.70 \pm 0.12$.

Analysis of 34 clast fabrics from nine different sites on four drumlins and from one site in an interdrumlin area (Sites 2, 10, 12, 14, 22, 24, 25, 27, and 28 in Fig. 5, as well as others from a stream cut near Sites 1 and 2) complemented the AMS fabric analysis. Clast fabrics were similar 
to AMS fabrics in that clast long axes were distinctly clustered, with no girdled fabrics (online supplementary material). The range in fabric strengths of the clast fabrics was narrower $\left(S_{1}=\right.$ 0.51-0.86) than for the AMS fabrics, with an average of $S_{1}=0.71 \pm 0.09$. All but two of the fabrics $\left(94 \%\right.$ of the total) were sufficiently strong to have directional significance $\left(S_{1}>0.57\right)$.

Bootstrapping collective drumlin and interdrumlin fabric data clarified trends in both derived shearing azimuths and shear-plane attitudes. Shearing azimuths and shear-plane orientations derived from fabrics (Figs. 10 and 11) vary systematically over the drumlins and interdrumlin areas. Azimuthal trends are similar for both AMS and clast fabrics in drumlins and tend to diverge (point away from the drumlin long-axis) upglacier of the drumlin crest and converge (point toward the drumlin long axis) downglacier of it, whereas orientations derived from AMS fabrics at interdrumlin sites tend to align in the direction of glacier flow, as indicted by the trends of the long axes of drumlins (Fig. 10). For the drumlins, these azimuths correspond to the trends of the contours of the drumlin surface at the sites where fabric samples were collected, with the majority of the bootstrapped data falling within one standard deviation of the average azimuths of the drumlin surface contours (Fig. 10). Clast long axis azimuthal trends, where measured, are similar to shear azimuths obtained from AMS fabrics. Too few clast fabrics $(<5)$ were measured in the other drumlin quadrants and in the interdrumlin areas to perform bootstrap analyses on the data.

Shear-plane attitudes determined from AMS fabrics from drumlins were significantly different on the opposing lateral flanks of drumlins (Figs. 11 and 12). Shear planes tended to dip in the same direction as the drumlin surface, and dips, on average, did not exceed the drumlin surface 
slope. Shear planes inferred from AMS fabrics of interdrumlin areas also conformed to the topography there, with strikes that were intermediate to those of the two drumlin flanks and gentle downglacier dips consistent with the overall slope of the glacier forefield (Fig. 7).

\subsection{Bullet boulders}

Orientations of striations on bullet boulders indicated a slight divergence in flow azimuths on the stoss sides of drumlins (average azimuthal difference of $10.7 \pm 8.6^{\circ}$ between the two drumlin flanks) and slight convergence on their lee sides (average azimuthal difference of $21.6 \pm 10.7^{\circ}$ between the two drumlin flanks) (Fig. 13), although this pattern was not apparent everywhere. Where observed, the degree of divergence and convergence was roughly comparable to that of the till fabric data (Fig. 10). The average azimuths of striations on some drumlins trended southwest of drumlin long axes by up to $\sim 15^{\circ}$ (e.g., Fig. 13d).

\subsection{Consolidation and effective stress}

Consolidation in the fine-grained component of the Múlajökull tills sampled for AMS measurements indicated that subglacial till in interdrumlin areas was under higher effective pressure than till within drumlins. The average dry bulk densities of till samples collected from the heads and tails of drumlins were lower $\left(1639 \pm 119 \mathrm{~kg} \mathrm{~m}^{-3}\right.$ and $1650 \pm 124 \mathrm{~kg} \mathrm{~m}^{-3}$, respectively) than the average density of samples collected from interdrumlin areas $(1817 \pm 112$ $\mathrm{kg} \mathrm{m}^{-3}$ ). Two-tailed t-tests applied to the two sets of till densities show that differences in density between tills from drumlins (both heads and tails) and those from interdrumlin areas are significant $(\mathrm{p}<0.01$, indicating a less than $1 \%$ probability that the data sets are not statistically distinct). Individual site results are reported in Table 1. The virgin compression curve determined 
for the Múlajökull tills (Table 2, Fig. 14) showed that these tills have a compressibility that falls near values observed for other tills (e.g., Koechlein, 1968; Sauer and Christiansen, 1991; Tulaczyk et al., 2000), with a compressibility index of $C_{c} \approx 0.20 \pm 0.05$. This value indicates a difference in past maximum effective stress between the drumlin and interdrumlin areas on the order of $100 \mathrm{kPa}$. An alternative interpretation - that the difference in till density between drumlins and interdrumlin areas resulted from differences in till texture - is discounted by grain-size data that indicate no significant difference in the textures of till sampled from drumlins and interdrumlin areas (Fig. 15).

\section{DISCUSSION}

\subsection{Elevation profiles}

We interpret higher glacier forefield elevations near the ice margin (Fig. 7) to reflect thicker proglacial sediment there. The alternative interpretation - that bedrock in the forefield slopes similarly away from the glacier — is unlikely to be correct because the glacier has an overdeepened bed just upstream of the current margin (Minchew et al., 2016), suggesting that if the bedrock surface indeed slopes, it is more likely to slope away from the Little Ice Age moraine and toward the glacier than away from it. Additionally, the radial symmetry of the topographic profiles mimics that of the glacier margin, indicating that the slopes of the profiles reflect glacier flow rather than structural or lithologic control by bedrock. Thus, the observation that elevation is highest inside the 1992 surge moraine implies that the four surges that terminated near that moraine (Fig. 1) caused preferential deposition there, resulting in the observed break in slope outside the moraine limit (Fig. 7). The alternative possibility that the sediments were once even thicker upstream of the 1992 moraine but have been eroded by recent 
surging to cause the break in slope is untenable because such net erosion is contradicted by proximal basal till units that can be traced to surge moraines at Múlajökull (Johnson et al., 2010; Benediktsson et al., 2016). In the case of the 2008 surge, the associated till drapes both drumlins and interdrumlin areas. Thus, although there is stratigraphic evidence that both erosion and deposition helped form drumlins at Múlajökull (Johnson et al., 2010; Benediktsson et al., 2016), these observations suggest that that drumlin growth was accompanied by net aggradation and, specifically, that the surge phases of surge cycles were aggradational.

\subsection{Fabrics and bullet boulders}

AMS fabrics from ring-shear experiments (Fig. 8) provide the experimental justification for confidently interpreting AMS till fabrics developed through simple shear at Múlajökull. These experimental results mimic those obtained during ring-shear testing of other tills that contain a form of magnetite as the dominant magnetic mineral (Hooyer et al., 2008). Clustered principalsusceptibility orientations clearly result from shear, with clusters orientated predictably with respect to the azimuth and plane of shearing (see also Fig. $4 \mathrm{a}$ ). Steady-state, $k_{l}$-based fabric strengths are lower in the Múlajökull till than in other basal tills that have been sheared experimentally, perhaps reflecting the texture of the Múlajökull till: the coarsest till that has been sheared, to date, in experiments to determine AMS fabrics. Preferred alignment of the fine silt particles that control AMS fabric is expected to be less in till with more coarse grains that require more accommodation by matrix particles during shear.

Fabrics from the Múlajökull forefield provide information about the three-dimensional strain in the till of the drumlins. Both AMS and clast fabrics show clustering of principal-susceptibility 
and long-axis orientations, respectively, consistent with the primary strain regime being simple shear. No fabric provides evidence of the longitudinally-compressive strain regimes manifested as girdled $k_{1}$ and $k_{2}$ orientations (Fig. 4b), both observed in compressional moraines (Ankerstjerne et al., 2015) and expected in drumlins if their relief reflects longitudinal compression and upward extension from locally negative sediment flux divergence (e.g., Fowler and Chapwanya, 2014). Moreover, in most drumlin fabric studies — whether authors relied on AMS fabrics (Gentoso et al., 2011; Vreeland et al., 2015; Hopkins et al., 2016) or clast fabrics (e.g., Wright, 1957; Hill, 1971; Karczewski, 1987; Piotrowski and Smalley, 1987; Goldstein, 1989, 1994; Jørgensen and Piotrowski, 2003; Menzies and Brand, 2007; and 15 other studies cited by Stokes et al., 2011)—only fabrics consistent with simple shear have been identified.

Orientations of these shear fabrics suggest that till was deposited progressively on existing drumlin forms, thereby contributing to drumlin relief. Shearing azimuths diverge on the upglacier ends of drumlins and converge on their downglacier ends (Fig. 10), indicating that till shearing and deposition were affected by the drumlin forms. Convergent fabrics do not agree with squeezing or shearing of till away from drumlin long axes, like that required of the shearinstability hypothesis to generate the lateral relief of drumlins (Fowler and Chapyanwa, 2014). Shear planes dip away from drumlin long axes and toward their flanks on both sides (Fig. 11a) consistent with the attitudes of some till beds (Benediktsson et al., 2016)-implying deposition on drumlin slopes. These observations help rule out the possibility that the drumlins formed exclusively by erosion of preexisting till beds (e.g., Vreeland et al., 2015; Eyles et al. 2016). Fabrics conforming to drumlin shapes often have been observed in clast and AMS fabric studies of other drumlins (e.g., Savage, 1968, as cited in Stokes et al., 2011; Walker, 1973; Krüger and 
Thomsen, 1984; Hopkins et al., 2016). Furthermore, fabrics from interdrumlin areas have shearing azimuths that trend parallel to the long axes of immediately adjacent drumlins (Fig. 10) and shear planes that—like the average forefield surface — dip slightly downglacier (Fig. 11b). Thus, fabrics of interdrumlin-area tills also agree with general topographic trends.

The orientations of striations on bullet boulders (Fig. 13) provide the most recent pattern of ice flow across the drumlins and indicate flow divergence and convergence of comparable magnitude to that indicated by the till fabrics (Fig. 10). Thus, the degree of flow divergence and convergence indicated by those fabric data, although small, is reinforced by the bullet-boulder data. The tendency for some striations to trend slightly to the southwest of drumlin long axes may indicate, somewhat unsurprisingly, that the most recent flow of ice across some drumlins had a slightly different azimuth than the average azimuth of the previous flow regimes that shaped these drumlins.

\subsection{Consolidation and effective stress}

Bulk density measurements show that tills from interdrumlin areas are generally more consolidated than drumlin sediments (Table 1), and average density differences on the order of $200 \mathrm{~kg} \mathrm{~m}^{-3}$ indicate that sediments in interdrumlin areas experienced maximum effective stresses on the order of $100 \mathrm{kPa}$ higher than in drumlin areas. Effective stresses were likely higher during periods of normal flow between surges (quiescent phases), when subglacial water flows in channels at water pressures lower than those in less efficient drainage systems during surges (e.g., Kamb et al., 1985). Therefore, maximum consolidation of the Múlajökull tills likely occurred during quiescent flow, such that the tills acquired their densities and preconsolidation 
pressures between surges. Thus, effective stresses were higher between drumlins than within them during quiescent periods.

This pattern of effective stress during quiescent flow is consistent with diverse observations from the study area. Higher effective stresses between drumlins than within them is compatible with observations that crevasses in the glacier tend to be concentrated over drumlins, which would reduce total normal stresses on the bed there (Johnson et al., 2010; Benediktsson et al., 2016). Water-escape structures - dike-like accumulations of massive to laminated silt to coarse sand deposited by subglacial groundwater flow that dip away from the drumlin crest and toward its flanks and the adjacent interdrumlin area—indicate larger hydraulic heads within drumlins than between them, also in agreement with low effective stresses within drumlins (Benediktsson et al., 2016). Also consistent with these observations is that the current glacier margin in its quiescent state is drained of subglacial water by tunnels with portals that generally occupy low regions between drumlins. The position of these tunnels, which undoubtedly run at lower water pressures than adjacent regions of the bed and thus collect water from them, reinforces the inference that basal water moved from drumlins toward interdrumlin areas under head gradients that helped to cause lower effective stresses in drumlins than between them. This effective stress pattern conflicts with the bed heterogeneity (Boulton, 1987) and interfacial instability hypotheses (e.g., Fowler and Chapwanya, 2014), which require that effective stresses in interdrumlin areas be lower than in drumlins to produce drumlin relief. Thus, a different hypothesis is needed to explain drumlin formation at Múlajökull. 


\subsection{Drumlin formation at Múlajökull}

The results of this study and previous work at Múlajökull indicate that the drumlins there developed during overall aggradation of the glacier forefield and that till deposition occurred on drumlin slopes, thereby contributing to their relief. However, erosion of till likely also contributed to drumlin relief, as indicated by unconformities at the drumlin flanks (Johnson et al., 2010; Benediktsson et al., 2016) and at the head of a drumlin with a rare longitudinal stream cut (Benediktsson et al., 2016). Johnson et al. (2010) suggested that both erosion and deposition occurred during surge phases of the surge cycle. Clearly, surges result in the deposition of till layers, given that layers can sometimes be traced to surge moraines (Johnson et al., 2010; Benediktsson et al., 2016). Importantly, the most recent surge of the glacier in 2008 left a till that is continuous everywhere on the proximal side of the 2008 moraine (Fig. 2) (Jónsson et al., 2014). This observation motivates an alternative hypothesis: that surges are depositional everywhere and that the erosion that helps amplify drumlin relief occurs during quiescent flow of the glacier.

This hypothesis is attractive because deposition of debris from basal ice is expected during surging due to high rates of frictional melting. Basal melt rates, which depend on the product of basal slip velocity and basal shear stress, will increase dramatically during surge events due to order-of-magnitude increases in slip velocity, probably associated with shear deformation of the bed. If shear deformation is pervasive and uniform, as might be expected owing to the uniformly high water pressures of the distributed hydrologic system expected during surging, then uniform release of debris from ice is expected across the bed. In the thin zone at the bed surface where resultant lodgement occurs, till will be sheared, which will result in shear fabrics across the 
thicknesses of progressively accreted till layers. An alternative is that bed deformation during surging mobilizes till from upglacier, advects it downglacier by shear deformation, and emplaces basal till superimposed on previously deposited till layers. We, however, see no independent reason for asserting that bed deformation should necessarily lead to net aggradation. Regardless of the sediment transport mechanism, a layer of basal till is deposited everywhere in the glacier forefield, as clearly exemplified by the surge of 2008, causing overall aggradation of the glacier bed.

Our hypothesis that erosion occurred between drumlins during normal quiescent flow is consistent with the measured distribution of till density and tendency of subglacial channels to occupy areas between drumlins during quiescent periods. Water flow in channels between drumlins may have been directly responsible for substantial sediment transport and erosion (e.g., Alley et al., 1997; Clarke, 2005). In addition, however, both till density gradients and channels, at low water pressure between drumlins indicate that effective stresses on the bed increased toward channels.

Importantly, rates of subglacial sediment transport likely increase with increasing effective stress. Depths of regelation infiltration of ice into sediments and subsequent transport of debris in ice (e.g., Iverson and Semmens, 1995; Hindmarsh, 1997; Clarke, 2005; Rempel, 2008) increase linearly with effective stress and will thus increase toward channels (Iverson, 2000; Rempel, 2009). Also, some field and modeling studies indicate that the thickness of shearing till layers increases with increasing effective stress on the bed, as long as effective stresses are not too large to frictionally inhibit shear. Subglacial measurements indicate that ice-bed coupling is reduced 
and the depth of bed deformation decreases—-such that deformation is increasingly focused near the glacier sole—with decreasing effective stress (Fischer and Clarke, 1997; Engelhardt and Kamb, 1998; Iverson et al., 1999; Boulton et al., 2001; Iverson et al., 2007), and discrete element modeling of bed shear agrees with this finding (Damsgaard et al., 2013). Larger deforming layer thicknesses where effective stresses in the bed were highest would have caused a net till flux out of interdrumlin areas if rates of basal slip were comparable on and between drumlins.

This hypothesis, if taken at face value, would imply that drumlins formed by non-surge-type glaciers would tend to be dominantly erosional. Many previous researchers have suggested, however, based on seemingly solid evidence from Pleistocene drumlins, that both deposition and erosion played a role in drumlin formation (e.g., Whittecar and Mickelson, 1977; Stea and Brown, 1989; Ellwanger, 1992; Goldstein, 1994). Either the poorly known flow dynamics of the parts of the ice sheets that made these drumlins included periods of fast flow with associated till deposition, or the conceptual model advocated here —of erosion during quiescent flow and deposition restricted to surges - is overly simplified. Although the latter is likely, formulation of better models, whether conceptual or quantitative, will require better data on subglacial sediment transport mechanisms and their spatial and temporal distributions.

In a recent conceptual model of drumlin formation, Eyles et al. (2016) argued that most drumlins display evidence of autochthonous cores of antecedent till, other sediments, or rock, and have "grown down" by erosion. They suggested that erosion occurs differentially at the bases of thin $(<1 \mathrm{~m})$ shearing till layers to form drumlins in a process analogous to erosion of streamlined surfaces at the bases of gravity-driven mass flows and at the surfaces of faults. Our observations 
at Múlajökull do not agree with the erosional regime of the Eyles et al. model: the proximal part of the glacier forefield (inside the 1992 surge moraine), which contains the most elongate drumlins and has been subjected to the most surges, has undergone net aggradation relative to the distal part of the forefield.

\section{CONCLUSIONS}

Drumlins of the Múlajökull forefield are the product of both till deposition and erosion. The drumlins evolve through iterations of these two processes that are likely controlled by the glacier's surge cycle. Although the exact sediment transport processes that contribute to drumlin formation are not evident from this work, the physical characteristics of the drumlins provide clear constraints on their formation:

- The package of basal tills that dominates the stratigraphy of the drumlins thickens with proximity to the glacier, where the forefield has experienced more surging. This observation, along with the observation that the 2008 advance was accompanied by deposition of a new till unit (Benediktsson et al., 2016), suggests that the Múlajökull forefield has aggraded progressively during successive surges and progressive drumlin development.

- AMS and clast fabrics within the drumlins indicate that both near-surface and deeper tills (up to a depth of $5.9 \mathrm{~m}$ ) have been subjected dominantly to shear strain, with no evidence of girdled fabrics that are associated with longitudinal compressional strain.

- Till shearing azimuths based on AMS and clast fabrics diverge at drumlin heads and converge at drumlin tails, whereas sediments from interdrumlin areas have shearing 
azimuths approximately parallel to the long axes of adjacent drumlins. Till shear planes based on AMS fabrics on the flanks of drumlins dip away from drumlin long axes in the direction of surface slopes, similar to the attitudes of till beds observed within some drumlins (Benediktsson et al., 2016). In interdrumlin areas, on the other hand, shear planes dip slightly downglacier in the same direction as the forefield surface. Thus, tills of both drumlins and interdrumlin areas were sheared in orientations that conformed to the local topography, indicating drumlins grew partly by deposition of till.

- Systematic variations in till density indicate that tills of interdrumlin areas were under higher past maximum effective stresses than tills within drumlins. Till consolidation patterns likely reflect quiescent flow periods, when effective stresses can be inferred to have been higher than during surges.

- Till density data indicating that drumlins are less consolidated than intervening areas contradict both the bed-heterogeneity (Boulton, 1987) and the shear-instability (e.g., Fowler and Chapawanya, 2014) hypotheses for drumlin formation. Till AMS data lacking indication of longitudinally-compressive strain further contradict shear-instability hypotheses.

The observation that the last surge of the glacier in 2008 deposited a till layer both on and between drumlins, together with unconformities observed on drumlin flanks (Johnson et al., 2010; Benediktsson et al., 2016), motivate a new hypothesis for drumlin formation at Múlajökull: till may have been deposited during surges and eroded from interdrumlin areas during quiescent flow periods. Stratigraphic evidence connecting specific till layers to other surge moraines (Johnson et al., 2010) reinforces that deposition occurred during surges. Whether 
sediment transport downglacier during surges was predominantly by lodgment associated with high rates of basal melting or by advection of till in a deforming bed, AMS fabrics, as noted, indicate that compressional or extensional strain was not responsible for drumlin relief. Rather during quiescent flow, subglacial channels between drumlins would have contributed to erosion there. Moreover, effective stresses that increased toward these low-pressure channels would have promoted net till flux out of areas between drumlins by regelation infiltration and by shear deformation of the bed.

\section{ACKNOWLEDGMENTS}

We thank J. Amato, J. Esler, J. Friðriksson, G. Gadd, M. Harbury, L. Ives, S. Jónsson, E. Joynt, I. McBrearty, J. Schneider, C. Thomsen, and S. Tomer, for their assistance in the field. We also thank M. Bennett, T. Fisher, and the anonymous reviewer whose thoughtful comments helped to improve the paper. This work was supported by grants from the US National Science Foundation (grant EAR-1225812), the Geological Society of America Graduate Student Research Grants, The Carlsberg Foundation (grants 2008-01-0376 and 2009-01-0069), The Landsvirkjun Energy Research Fund, The University of Iceland Research Fund, the Icelandic Research Fund RANNÍS (grant 110237023), and the Royal Physiographic Society in Lund.

\section{REFERENCES}

Allen, J.R.L. (1985). Principles of Physical Sedimentology. London: George Allen and Unwin. Alley, R.B., K.M. Cuffey, E.B. Evenson, J.C. Strasser, D.E. Lawson, and G.J. Larson (1997). How glaciers entrain and transport basal sediment: Physical constraints. Quaternary Science Reviews 16: 1017-1038. 
Ankerstjerne, S.M., N.R. Iverson, and F. Lagroix (2015). Origin of a washboard moraine of the Des Moines Lobe inferred from sediment properties. Geomorphology 248: 452-463.

Benediktsson, Í.Ö., A. Schomacker, M.D. Johnson, A.J. Geiger, Ó. Ingólfsson, and E.R. Guðmundsdóttir (2015). Architecture and structural evolution of an early Little Ice Age terminal moraine at the surge-type glacier Múlajökull, Iceland. Journal of Geophysical Research-Earth Surface 120: 1895-1910.

Benediktsson, Í.Ö., S.A. Jónsson, A. Schomacker, M.D. Johnson, Ó. Ingólfsson, L.K. Zoet, N.R. Iverson, and J. Stötter (2016). Progressive formation of modern drumlins at Múlajökull, Iceland: Stratigraphic and morphological evidence. Boreas 45: 10.1111/bor.12195.

Björnsson, H., F. Pálsson, O. Sigurðsson, and G. Flowers (2003). Surges of glaciers in Iceland. Annals of Glaciology 36: 82-90.

Borradaile, G.J. and M. Jackson (2004). Anisotropy of magnetic susceptibility (AMS): magnetic petrofabrics of deformed rocks. Geological Society of London, Special Publications 238: 299-360.

Boulton, G.S. (1978). Boulder shapes and grain-size distributions of debris as indicators of transport paths through a glacier and till genesis. Sedimentology 25: 773-779.

Boulton, G.S. (1987). A theory of drumlin formation by subglacial sediment deformation. In J.M. Menzies and J. Rose (Eds.), Drumlin Symposium. Rotterdam: Balkema, pp. 25-80. Boulton, G.S. (1996). Theory of glacial erosion, transport and deposition as a consequence of subglacial sediment deformation. Journal of Glaciology 42: 43-62.

Boulton, G.S., K.E. Dobbie, and S. Zatsepin (2001). Sediment deformation beneath glaciers and its coupling to the subglacial hydraulic system. Quaternary International 86: 3-28. 
Boyce, J.I., and N. Eyles (1991). Drumlins carved by deforming till streams below the Laurentide Ice Sheet. Geology 19: 787-790.

Briner, J.P. (2007). Supporting evidence from the New York drumlin field that elongate subglacial bedforms indicate fast flow. Boreas 36: 143-147.

Butler, R.F., G.E. Gehrels, S.L. Baldwin, and C. Davidson (2002). Paleomagnetism and geochronology of the Ecstall pluton in the Coast Mountains of British Columbia: Evidence for local deformation rather than large-scale transport. Journal of Geophysical Research--Solid Earth 107(3): 1-13.

Clark, C.D. (2010). Emergent drumlins and their clones: From till dilatancy to flow instabilities. Journal of Glaciology 51: 1011-1025.

Clark, C.D., A.L.C. Hughes, S.L. Greenwood, M. Spagnolo, and F.S.L. Ng (2009). Size and shape characteristics of drumlins, derived from a large sample, and associated scaling laws. Quaternary Science Reviews 28: 677-692.

Clarke, G.K.C. (1987). Subglacial till: A physical framework for its properties and processes. Journal of Geophysical Research—Solid Earth 92: 9023-9036.

Clarke, G.K.C. (2005). Subglacial processes. Annual Review of Earth and Planetary Sciences 33: 247-276.

Constable, C.G. and L. Tauxe (1990). The bootstrap for magnetic susceptibility tensors. Journal of Geophysical Research—Solid Earth 95: 8383-8395.

Damsgaard, A., D.L. Egholm, J.A. Piotrowski, S. Tulaczyk, N.K. Larsen, and K. Tylmann (2013). Discrete element modelling of subglacial sediment deformation. Journal of Geophysical Research—Earth Surface 118: 2230-2242. 
Das, B.M. (2010). Principles of Geotechnical Engineering, 6th Ed. Pacific Grove, CA: Thompson Learning, Inc.

de Wall, H., and H.U. Worm (2000). A cautionary note on interpreting frequency-dependence of susceptibility solely in terms of paramagnetism. The IRM Quarterly, Vol. 10. Minneapolis, MN, Institute for Rock Magnetism.

Dillner, J.G. (2011). Stratigrafi, sedimentology och genes av till vid Múlajökull, Island. MS Thesis, University of Gothenburg.

Domeier, M., R. Van der Voo, R.T. Tomezzoli, E. Tohver, B.W.H. Hendriks, T.J. Torsvik, H. Vizan, and A. Dominguez (2011). Support for an "A-type" Pangea reconstruction from high-fidelity Late Permian and Early to Middle Triassic paleomagnetic data from Argentina. Journal of Geophysical Research--Solid Earth 116: 10.1029/2011JB008495.

Dunlop, D.J. (2002). Theory and application of the Day plot (Mrs/Ms versus $\mathrm{Hrc} / \mathrm{Hc}) 1$. Theoretical curves and tests using titanomagnetite data. Journal of Geophysical Research—Solid Earth 107: 10.1029/2001JB000487.

Efron, B. (1982). The Jackknife, the Bootstrap, and Other Resampling Plans. Philadelphia, PA: Society for Industrial and Applied Mathematics.

Efron, B., and R. Tibshirani (1986). Bootstrap methods for standard errors, confidence intervals, and other measures of statistical accuracy. Statistical Science 1: 54-77.

Ellwanger, D. (1992). Lithology and stratigraphy of some Rhine drumlins (South German Alpine Foreland). Geomorphology 6: 79-88.

Engelhardt, H., and B. Kamb (1998). Basal sliding of Ice Stream B, West Antarctica. Journal of Glaciology 44: 223-230. 
Eyles, N., N. Putkinen, S. Sookhan, and L. Arbelaes-Moreno (2016). Erosional origin of drumlins and megaridges. Sedimentary Geology: 10.1016/JSEDGEO201601006.

Fischer, U.H., and G.K.C. Clarke (1997). Stick-slip behaviour at the base of a glacier. Annals of Glaciology 24: 390-396.

Fowler, A.C. (2009). Instability modeling of drumlin formation incorporating lee-side cavity growth. Proceedings of the Royal Society: Mathematical, Physical and Engineering Sciences 465: 2681-2702.

Fowler, A.C. (2010). The formation of subglacial streams and mega-scale glacial lineations. Proceedings of the Royal Society A-Mathematical, Physical and Engineering Sciences 466: 3181-3201.

Fowler, A.C., and M. Chapwanya (2014). An instability theory for the formation of ribbed moraine, drumlins, and mega-scale glacial lineations. Proceedings of the Royal Society A—Mathematical, Physical, and Engineering Sciences 470: 10.1098/RSPA20140185.

Gentoso, M.J., E.B. Evenson, K.P. Kodama, N.R. Iverson, R.B. Alley, C. Berti, and A. Kozlowski (2011). Exploring till bed kinematics using AMS magnetic fabrics and pebble fabrics: the Weedsport drumlin field, New York State, USA. Boreas 41: 31-41.

Goldstein, B. (1989). Lithology, sedimentology, and genesis of the Wadena drumlin field, Minnesota, USA. Sedimentary Geology 62: 241-277.

Goldstein, B. (1994). Drumlins of the Puget lowland, Washington state, USA. Sedimentary Geology 91: 299-311.

Granot, R., M. Abelson, H. Ron, M.W. Lusk, and A. Agnon (2011). Direct evidence for dynamic magma supply fossilized in the lower oceanic crust of the Troodos ophiolite. Geophysical Research Letters—Solid Earth 38: 10.1029/2011GL048220. 
Haselton, G.M. (1966). Glacial geology of Muir Inlet, southeast Alaska. Ohio State University Institute of Polar Studies Report 18, pp 18.

Hill, A.R. (1971). The internal composition and structure of drumlins in North Down and South Antrim, Northern Ireland. Geografiska Annler-Series A, Physical Geography 53: 14-31.

Hindmarsh, R.C.A. (1997). Deforming beds: Viscous and plastic scales of deformation. Quaternary Science Reviews 16: 1039-1056.

Hindmarsh, R.C.A. (1998). Drumlinization and drumlin-forming instabilities: Viscous till mechanisms. Journal of Glaciology 44: 293-314.

Hindmarsh, R.C.A. (1999). Coupled ice-till dynamics and the seeding of drumlin and bedrock forms. Annals of Glaciology 28: 221-230.

Hobbs, B.E., W.D. Williams, and P.F. Williams (1976). An Outline of Structural Geology. New York: John Wiley and Sons.

Hooke, R.LeB. and A. Medford (2013). Are drumlins the produce of a thermos-mechanical instability? Quaternary Research 79: 458-464.

Hooyer, T.S., N.R. Iverson, F. Lagroix, and J.F. Thomason (2008). Magnetic fabric of sheared till: A strain indicator for evaluating the bed deformation model of glacier flow. Journal of Geophysical Research—Earth Surface 113: 10.1029/2007JF00757.

Hopkins, N.R., E.B. Evenson, K.P. Kodama, and A.L. Kozlowski (2016). An anisotropy of magnetic susceptibility investigation of the till fabric of drumlins: Support for an accretionary origin. Boreas 45(1): 100-108.

Iverson, N.R. (2000). Sediment entrainment by a soft-bedded glacier: a model based on regelation infiltration into the bed. Earth Surface Processes and Landforms 25: 881-893. 
Iverson, N.R. (2010). Shear resistence and continuity of till at glacier beds: hydrology rules. Journal of Glaciology 56: 1104-1114.

Iverson, N.R., and D.J. Semmens (1995). Intrusion of ice into porous media by regelation: A mechanism of sediment entrainment by glaciers. Journal of Geophysical Research--Solid Earth 100: 10219- 10230.

Iverson, N.R., R.W. Baker, and T.S. Hooyer (1997). A ring-shear device for the study of till deformation: Tests on a clay-rich and a clay-poor till. Quaternary Science Reviews 16: 1057-1066.

Iverson, N.R., T.S. Hooyer, and R.W. Baker (1998). Ring-shear studies of till deformation: Coulomb-plastic behaviour and distributed strain in glacier beds. Journal of Glaciology 44: 634-641.

Iverson, N.R., R.W. Baker, R.LeB. Hooke, B. Hanson, and P. Jansson (1999). Coupling between a glacier and a soft bed: I. A relation between effective pressure and local shear stress determine from till elasticity. Journal of Glaciology 45: 31-40.

Iverson, N.R., T.S. Hooyer, U.S. Fischer, D. Cohen, P.L. Moore, M. Jackson, G. Lappegard, and J. Kohler (2007).Soft-bed experiments beneath Engabreen, Norway: Regelation infiltration, basal slip, and bed deformation. Journal of Glaciology 53: 323-340.

Iverson. N.R., T.S. Hooyer, J.F. Thomason, M. Graesch, and J.R. Shumway (2008). The experimental basis for interpreting particle and magnetic fabrics of sheared till. Earth Surface Processes and Landforms 33: 627-645.

Ives, L.R.W. (2016). Magnetic mineralogy and fabrics of small-scale glacial flutes, Múlajökull and Breiðamerkurjökull, Iceland. MS Thesis, Iowa State University. 
Jóhannesson, T., H. Björnsson, F. Pálsson, O. Siguðsson, and Th. Thorsteinsson (2011). LiDAR mapping of the Snæfellsjökull ice cap, western Iceland. Jökull 61: 19-32.

Johnson, M.D., A. Schomacker, Í.Ö. Benediktsson, A.J. Geiger, A. Ferguson, Ó. Ingólfsson (2010.) Active drumlin field revealed at the margin of Múlajökull, Iceland: A surge-type glacier. Geology 38: 943-946.

Jónsson, S.A., A. Schomacker, Í.Ö. Benediktsson, Ó. Ingólfsson, M.D. Johnson (2014). The drumlin field and the geomorphology of the Múlajökull surge-type glacier, central Iceland. Geomorphology 207: 213-220.

Jørgensen, F., and J.A. Piotrowski (2003). Signature of the Baltic Ice Stream on Funen Island, Denmark during the Weichselian glaciation. Boreas 32: 242-255.

Kamb, B. (1991). Rheological non-linearity and flow instability in the deforming bed mechanism of ice stream motion. Journal of Geophysical Research-Solid Earth 96: 16585-16595.

Kamb, B., C.F. Raymond, W.D. Harrison, H. Englehardt, K.A. Echelmeyer, N. Humphrey, M.M. Brugman, and T. Pfeffer (1985). Glacier surge mechanism: 1982-1983 surge of Variegated Glacier, Alaska. Science 227: 469-479.

Karczewski, A. (1987). Lithofacies variability of a drumlin in Pomerania, Poland. In J.M. Menzies and J. Rose (Eds.), Drumlin Symposium. Rotterdam: Balkema, pp.177-183.

King, E.C., J. Woodward, and A.M. Smith (2007). Seismic and radar observations of subglacial bedforms beneath the onset zone of the Rutford Ice Stream, Antarctica. Journal of Glaciology 183: 665-672.

King, E.C., R.C.A. Hindmarsh, and C.R. Stokes (2009). Formation of mega-scale glacial lineations observed beneath a West Antarctic ice stream. Nature Geoscience 2: 585-588. 
Knight, J. (2014). Subglacial hydrology and drumlin sediments in Connemara, Western Ireland. Geografiska Annaler: Series A, Physical Geography 96: 403-415.

Koechlein, W.H. (1968). The compressibility of preconsolidated till. MS Thesis, Missouri University of Science and Technology.

Krüger, J. (1984). Clasts with stoss-lee form in lodgement tills: a discussion. Journal of Glaciology 30: 241-243.

Krüger, J. (1987). Relation of drumlin shape and distribution to drumlin stratigraphy and glacial history, Mýrdalsjökull, Iceland. In J.M. Menzies and J. Rose (Eds.), Drumlin Symposium. Rotterdam: Balkema, pp. 257-266.

Krüger, J., and H.H. Thomsen (1984). Morphology, stratigraphy, and genesis of small drumlins in front of the glacier Mýrdalsjökull, south Iceland. Journal of Glaciology 30: 94-105.

Lambe, T.W., and R.V. Whitman (1979). Soil mechanics, SI verion. New York: Wiley.

Mark, D.M. (1973). Analysis of axial orientation data, including till fabrics. Geological Society of America Bulletin 84: 1369-1374.

McCabe, A.M., and G.F. Dardis (1989). Sedimentology and depositional setting of Late Pleistocene drumlins, Galway Bay, Western Ireland. Journal of Sedimentary Petrology 59: 944-959.

Menzies, J.M. (1979). A review of the literature on the formation and location of drumlins. Earth Science Reviews 13: 315-349.

Menzies, J.M. and U. Brand (2007). The internal sediment architecture of a drumlin, Port Byron, New York state, USA. Quaternary Science Reviews 26: 322-335.

Moskowitz, B.M., M. Jackson, and C. Kissel (1998). Low-temperature magnetic behavior of titaonmagnetites. Earth and Planetary Science Letters 157: 141-149. 
Minchew, B., M. Simons, H. Björnsson, F. Pálsson, M. Morlighem, H. Seroussi, E. Larour, S. Hensley (2016). Plastic bed beneath Hofsjökull Ice Cap, central Iceland, and the sensitivity of ice flow to surface meltwater flux. Journal of Glaciology 62: 1-12.

Ó Cofaigh, C., C.J. Pudsey, J.A. Dodswell, and P. Morris (2002). Evolution of subglacial bedforms along a paleo-ice stream, Antarctic Peninsula continental shelf. Geophysical Research Letters 29: 411-414.

Owens, W.H. (1974). Mathematical model studies on factors affecting the anisotropy of deformed rocks. Tectonophysics 24: 115-131.

Ozima, M.L., E.E. (1970). Low- and high-temperature oxidation of titanomagnetite in relation to irreversible changes in the magnetic properties of submarine basalts. Journal of Geophysical Research 75: 1003-1017.

Patterson, C.J. and R.LeB. Hooke (1995). Physical environment of drumlin formation. Journal of Glaciology 41: 30-38.

Piotrowski, J.A., and I.J. Smalley (1987). The Woodstock drumlin field, southern Ontario, Canada. In J.M. Menzies and J. Rose (Eds.), Drumlin Symposium. Rotterdam: Balkema, pp. 309-321.

Piotrowski, J.A., and S. Tulaczyk (1999). Subglacial conditions under the last ice sheet in northwest Germany: ice-bed separation and enhanced basal sliding? Quaternary Science Reviews 18: 737-751.

Rabassa, J. (1987). Drumlins and drumlinoid forms in northern James Ross Island, Antarctic Peninsula. In J.M. Menzies and J. Rose (Eds.), Drumlin Symposium. Rotterdam: Balkema, pp. 267-288. 
Rempel, A.W. (2008). A theory for ice-till interactions and sediment entrainment beneath glaciers. Journal of Geophysical Research—Earth Surface 113: 10.1029/2007JF000870

Rempel, A.W. (2009). Transient effective stress variations forced by changes in conduit pressure beneath glaciers and ice sheets. Annals of Glaciology50: 61-66.

Sauer, E.K. and E.A. Christiansen (1991). Perconsolidation pressures in the Battleford Formation, southern Saskatchewan, Canada. Canadian Journal of Earth Sciences 28: 1613-1623.

Schomacker, A., J. Krüger, and K.H. Kjær (2006). Ice-cored drumlins at the surge-type glacier Brúarjökull, Iceland: A transitional-state landform. Journal of Quaternary Science 21: 85-93.

Schoof, C. (2007). Pressure-dependent viscosity and interfacial instability in coupled icesediment flow. Journal of Fluid Mechanics 570: 227-252.

Shaw, J. (1983). Drumlin formation related to inverted melt-water erosional marks. Journal of Glaciology 29: 461-479.

Sierra, F., A. Schedl, C. McCabe, and D.R. Robbins (1993). Deformation and magnetization of the Hudson Valley, eastern New York: Results of a study of calcite twinning and anisotropy of magnetic remanence in the Onondaga Limestone. Tectonophysics 217: 321329.

Sigurkarlsson, M.F. (2015). Surge history of Múlajökull, Iceland, since 1945 detected with remote sensing data. BS Thesis, University of Iceland.

Singh, K. and M. Xie (2008). Bootstrap: A statistical method. Unpublished manuscript. Rutgers University. Retrieved from: http://www. stat.rutgers.edu/home/mxie/RCPapers/bootstrap. 
Stea, R.R. and Y. Brown (1989). Variation in drumlin orientation, form, and stratigraphy relating to successive ice flows in southern and central Nova Scotia. Geology 62: 223-240.

Stevenson, C.T.E, W.H. Owens, and D.H.W. Hutton (2007). Flow lobes in granite: The determination of magma flow direction in the Trawenagh Bay Granite, northwestern Ireland, using anisotropy of magnetic susceptibility. Geological Society of America Bulletin 119: 1368-1386.

Stokes, C.R., M. Spagnolo, and C.D. Clark (2011). The composition and internal structure of drumlins: Complexity, commonality, and implications for a unifying theory of their formation. Earth Science Reviews 107: 398-422.

Tarling, D.H. and F. Hrouda (1993). The Magnetic Anisotropy of Rocks. London: Chapman and Hall.

Tauxe, L., S. Banerjee, R.F. Butler, and R. van der Voo. (2015). Essentials of Paleomagnetism. Berkley: University of California Press.

Thomason, J.F. and N.R. Iverson (2006). Microfabric and microshear evolution in deformed till. Quaternary Science Reviews 25: 1027-1038.

Tulaczyk, S.M., B. Kamb, and H.F. Englehardt (2000). Basal mechanics of Ice Stream B, West Antarctica: 1. Till mechanics. Journal of Geophysical Research-Solid Earth 105: 463481.

United States Department of Agriculture (2014). Soil Survey Laboratory Methods Manual (Soil Survey Laboratory Investigations Report No. 42), version 5. Lincoln: USDA. van der Meer, J.M. (1983). A recent drumlin with fluted surface in the Swiss Alps. In E.B. Evenson, Ch. Schlüchter, and J. Rabassa (Eds.) Tills and Related Deposits: Genesis, Petrology, Application, Stratigraphy. Rotterdam: Balkema, pp. 105-110. 
Verway, J.W. (1939). Electron conduction of magnetite (Fe3O4) and its transition point at low temperatures. Nature 144: 327-328.

Vreeland, N.P., N.R. Iverson, M. Graesch, and T.S. Hooyer (2015). Magnetic fabrics of the drumlins of the Green Bay Lobe, southeastern Wisconsin. Quaternary Science Reviews 112: 33-44.

Walker, M.J.C. (1973). The nature and origin of a series of elongated ridges in the Morley Flats Area of the Bow Valley, Alberta. Canadian Journal of Earth Science 10: 1340-1346.

Weil, A.B., A. Yonkee, and J. Kendall (2014). Towards a better understanding of the influence of basement heterogeneities and lithospheric coupling on foreland deformation: A structural and paleomagnetic study of Laramide deformation in the southern Bighorn Arch, Wyoming. GSA Bulletin 126: 415-437.

Whittecar, G.R., and D.M. Mickelson (1977). Sequence of till deposition and erosion in drumlins. Boreas 6: 213-217.

Wright, Jr., H.E. (1957). Stone orientation in Wadena drumlin field, Minnesota. Geografiska Annaler 39: 19-31. 


\section{APPENDIX A: Magnetic mineralogy of Múlajökull tills}

The magnetic mineralogy of the Múlajökull tills was studied by Ives (2016) using standard geomagnetic techniques: measurements of magnetic susceptibility as a function of temperature, magnetic remanence at low temperatures (20-300 K), magnetic susceptibility as a function of AC field frequency, and magnetic hysteresis, including generation of first-order reversal curves (FORC). Reversible Curie temperatures (measured upon heating and cooling) of $182{ }^{\circ} \mathrm{C}$ and $\sim 550{ }^{\circ} \mathrm{C}$ indicated that titanomagnetites with differing degrees of Ti substitution (Tauxe et al., 2015) were responsible for AMS. However, an irreversible value of $485^{\circ} \mathrm{C}$ indicated the presence of titanomaghemite and the oxidation of high-Ti titanomagnetites (Ozima, 1970; Moskowitz et al., 1998). Remanence-on-cooling curves for the Múlajökull till indicated a suppression of the Verwey transition (Verway, 1939) and abrupt decreases in magnetization at $\sim 60-80 \mathrm{~K}$, both of which are characteristic of titanomagnetite (Moskowitz et al., 1998). The inphase, room-temperature frequency dependence of magnetic susceptibility for the till was $5.38 \%$. This value is characteristic of multi-domain titanomagnetites with Curie temperatures of $~ 150$ $200{ }^{\circ} \mathrm{C}$ (de Wall and Worm, 2000), consistent with one of the Curie temperatures of this till. Magnetic hysteresis parameters were similar to natural and synthetic titanomagnetite samples with known grain sizes ranging from $1.5 \mu \mathrm{m}$ to $11.5 \mu \mathrm{m}$ (Dunlop, 2002). FORC distributions of Múlajökull tills indicated magnetic properties controlled by primarily pseudo-single domain grains with some multi-domain grains. Because $\sim 96 \%$ of the magnetic susceptibility for Múlajökull till comes from ferrimagnetic sources, any contribution to AMS from paramagnetic components was likely inconsequential. 
Importantly, elongate forms of titanomagnetites and titanomaghemite have shape-based

anisotropy of magnetic susceptibility, so that orientations of maximum susceptibility align with the long axes of grains. Like the tills studied by Hooyer et al. (2008) and Iverson et al. (2008), AMS fabrics of the Múlajökull till reflect the preferred alignment of silt-sized, ferrimagnetic, shape-anisotropic, pseudo-single domain and multi-domain particles.

\section{APPENDIX B: Supplementary material}

\section{TABLES}

TABLE 1: Dry bulk density $\left(\rho_{b}\right)$ values of till AMS samples, organized by site location (Fig. 5) and depth at which sample was taken.

\begin{tabular}{cccccc}
\hline Site & Location & Depth & $\mathbf{N}$ & $\boldsymbol{\rho}_{\boldsymbol{b}}$ & St. Dev. \\
\hline 1 & Drumlin (tail) & 0.90 & 26 & 1512 & 136.5 \\
\hline 1 & Drumlin (tail) & 2.10 & 21 & 1582 & 121.5 \\
2 & Drumlin (tail) & 2.80 & 24 & 1646 & 147.3 \\
\hline 2 & Drumlin (tail) & 0.30 & 25 & 1580 & 135.7 \\
2 & Drumlin (tail) & 1.60 & 28 & 1633 & 133.2 \\
2 & Drumlin (tail) & 2.40 & 26 & 1621 & 112.7 \\
3 & Drumlin (head) & 0.30 & 23 & 1885 & 136.5 \\
3 & Drumlin (head) & 0.30 & 24 & 1886 & 141.3 \\
3 & Drumlin (head) & 0.30 & 25 & 1878 & 91.6 \\
\hline 3 & Drumlin (head) & 0.75 & 21 & 1630 & 136.3 \\
4 & Drumlin (head) & 0.30 & 23 & 1915 & 94.95 \\
4 & Drumlin (head) & 0.90 & 18 & 1680 & 112.4 \\
5 & Interdrumlin & 0.30 & 18 & 1773 & 104.0 \\
\hline 5 & Interdrumlin & 0.55 & 24 & 1932 & 120.7 \\
6 & Interdrumlin & 0.30 & 23 & 1912 & 65.3 \\
7 & Drumlin (head) & 1.00 & 23 & 1619 & 134.8 \\
8 & Drumlin (tail) & 0.42 & 14 & 1841 & 111.5 \\
8 & Drumlin (tail) & 0.42 & 19 & 1747 & 111.9 \\
8 & Drumlin (tail) & 0.90 & 25 & 1791 & 155.1 \\
8 & Drumlin (tail) & 1.20 & 25 & 1680 & 106.1 \\
8 & Drumlin (tail) & 1.65 & 26 & 1635 & 122.1 \\
9 & Drumlin (tail) & 0.45 & 17 & 1605 & 126.1 \\
9 & Drumlin (tail) & 0.45 & 17 & 1610 & 61.1 \\
\hline
\end{tabular}


McCracken et al. 45

\begin{tabular}{|c|c|c|c|c|c|}
\hline 9 & Drumlin (tail) & 1.00 & 16 & 1668 & 85.7 \\
\hline 9 & Drumlin (tail) & 1.30 & 18 & 1597 & 121.6 \\
\hline 9 & Drumlin (tail) & 1.30 & 16 & 1708 & 134.9 \\
\hline 9 & Drumlin (tail) & 1.87 & 12 & 1571 & 64.7 \\
\hline 10 & Drumlin (head) & 0.96 & 16 & 1621 & 126.6 \\
\hline 10 & Drumlin (head) & 1.34 & 21 & 1551 & 119.2 \\
\hline 10 & Drumlin (head) & 1.50 & 21 & 1691 & 146.5 \\
\hline 11 & Drumlin (head) & 0.65 & 40 & 1831 & 163.1 \\
\hline 11 & Drumlin (head) & 0.73 & 11 & 1789 & 87.7 \\
\hline 12 & Drumlin (tail) & 0.58 & 20 & 1827 & 83.4 \\
\hline 12 & Drumlin (tail) & 0.66 & 21 & 1821 & 67.7 \\
\hline 12 & Drumlin (tail) & 0.76 & 17 & 1777 & 158.5 \\
\hline 13 & Drumlin* & 0.30 & 18 & 1727 & 125.3 \\
\hline 13 & Drumlin* & 0.51 & 36 & 1714 & 135.7 \\
\hline 13 & Drumlin* & 0.85 & 23 & 1587 & 103.4 \\
\hline 14 & Interdrumlin & 0.25 & 16 & 1800 & 77.2 \\
\hline 14 & Interdrumlin & 0.25 & 19 & 1865 & 94.3 \\
\hline 15 & Drumlin (head) & 0.30 & 20 & 1444 & 73.3 \\
\hline 15 & Drumlin (head) & 0.66 & 24 & 1673 & 146.2 \\
\hline 16 & Drumlin (head) & 0.40 & 14 & 1586 & 69.6 \\
\hline 16 & Drumlin (head) & 0.40 & 14 & 1503 & 111.2 \\
\hline 17 & Drumlin (tail) & 0.60 & 21 & 1675 & 119.3 \\
\hline 18 & Interdrumlin & 0.15 & 13 & 1746 & 70.9 \\
\hline 18 & Interdrumlin & 0.20 & 12 & 1868 & 92.2 \\
\hline 18 & Interdrumlin & 0.58 & 12 & 1944 & 85.3 \\
\hline 19 & Interdrumlin & 0.20 & 19 & 1762 & 102.5 \\
\hline 19 & Interdrumlin & 0.40 & 22 & 1572 & 110.0 \\
\hline 21 & Drumlin (tail) & 0.23 & 18 & 1375 & 101.0 \\
\hline 21 & Drumlin (tail) & 0.25 & 17 & 1483 & 137.7 \\
\hline 21 & Drumlin (tail) & 0.41 & 14 & 1490 & 133.4 \\
\hline 22 & Drumlin (head) & 0.65 & 19 & 1680 & 166.3 \\
\hline 22 & Drumlin (head) & 0.75 & 17 & 1657 & 131.4 \\
\hline 22 & Drumlin (head) & 2.10 & 13 & 1662 & 104.7 \\
\hline 23 & Drumlin (head) & 0.79 & 13 & 1637 & 118.0 \\
\hline 24 & Drumlin (head) & 0.46 & 12 & 1473 & 128.2 \\
\hline 24 & Drumlin (head) & 1.00 & 13 & 1569 & 89.4 \\
\hline 24 & Drumlin (head) & 1.63 & 26 & 1618 & 101.90 \\
\hline 24 & Drumlin (head) & 1.76 & 19 & 1501 & 139.8 \\
\hline 25 & Drumlin (head) & 0.24 & 16 & 1615 & 142.4 \\
\hline 25 & Drumlin (head) & 1.30 & 23 & 1552 & 87.5 \\
\hline 25 & Drumlin (head) & 1.60 & 26 & 1505 & 104.6 \\
\hline 26 & Drumlin (head) & 0.20 & 14 & 1515 & 128.5 \\
\hline 26 & Drumlin (head) & 0.55 & 17 & 1546 & 135.2 \\
\hline 27 & Drumlin (head) & 0.25 & 10 & 1428 & 1246.0 \\
\hline 27 & Drumlin (head) & 0.83 & 13 & 1651 & 68.3 \\
\hline 27 & Drumlin (head) & 1.48 & 22 & 1515 & 89.5 \\
\hline
\end{tabular}

* Site 13 was near the drumlin crest and was therefore difficult to classify as being at its head or tail. 
TABLE 2: Consolidation test results used to determine virgin compression curve.

\begin{tabular}{clcccccc}
\hline Site & $\boldsymbol{e}_{\mathbf{0}}$ & $\left.\boldsymbol{\rho}_{\boldsymbol{b}, \mathbf{0}} \mathbf{( k g ~ m}^{-3}\right)^{\boldsymbol{*}}$ & $\boldsymbol{\sigma}_{\mathbf{0}}^{\prime} \mathbf{( k P a )}$ & $\boldsymbol{e}_{\mathbf{0 . 4}}$ & $\left.\boldsymbol{\rho}_{\boldsymbol{b}, \mathbf{0 . 4}} \mathbf{( k g ~ m}^{-3}\right)^{\boldsymbol{*}}$ & $\boldsymbol{\sigma}_{\mathbf{0 . 4}}^{\prime} \mathbf{( k P a )}$ & $\boldsymbol{C}_{\boldsymbol{c}}$ \\
\hline 2 & 0.68 & 1605 & 21 & 0.27 & 2121 & 750 & 0.26 \\
2 & 0.78 & 1519 & 40 & 0.31 & 2060 & 17500 & 0.18 \\
3 & 0.62 & 1670 & 29 & 0.25 & 2160 & 19500 & 0.13 \\
4 & 0.76 & 1532 & 53 & 0.30 & 2069 & 15000 & 0.19 \\
14 & 0.70 & 1592 & 31 & 0.28 & 2112 & 1650 & 0.24 \\
\hline
\end{tabular}

* The relationship between the till's bulk density and its corresponding value of void ratio is $\rho_{b}=\rho_{\text {grains }}\left(\frac{e}{1-e}\right)$, where $\rho_{\text {grains }}$ is density of the sediment grains_-for Múlajökull, the density of basalt.

\section{FIGURE CAPTIONS}

FIGURE 1.

LiDAR hillshade map of Múlajökull and its forefield from 2013, with ice indicated by lightercolored shading and drumlins outlined in black. Moraines associated with (at least) six surges since 1945 (in 2008, 1992, 1986, 1979, 1972, and 1954) are included (moraines mapped by Jónsson et al., 2014; Sigurkarlsson, 2015). Locations of profile swaths (see text) used to characterize overall forefield surface topography also are shown (white dotted lines).

\section{FIGURE 2.}

Oblique view of Múlajökull drumlins, looking northeast, with 2008 moraine indicated (arrows).

\section{FIGURE 3.}

Drumlin stratigraphy in a stream cut roughly perpendicular to the drumlin long axis. Drumlin surface (solid line) and boundaries between till units (dashed lines) are indicated, along with till unit names from Benediktsson et al. (2016). A vertical surface extending $\sim 5.0 \mathrm{~m}$ below the drumlin surface was cleared for stratigraphic observations that are described in detail in 
Benediktsson et al. (2016). Note that the uppermost till unit truncates underlying till units near the drumlin flank (adapted from Benediktsson et al., 2016).

\section{FIGURE 4.}

Ellipsoids representing AMS fabrics that develop with different styles of strain and corresponding lower hemisphere stereonet plots in which $k_{l}$ orientations are represented by circles, $k_{2}$ orientations by squares, and $k_{3}$ orientations by crosses. (a) Steady-state orientation of the AMS ellipsoid that results from horizontally directed simple shear to a sufficient strain $(\sim 7$ 10). Principal-susceptibility orientations form distinct clusters when plotted on a lower hemisphere stereonet. (b) Orientation of AMS principal-susceptibility orientations under pure shear. When plotted on a lower hemisphere stereonet, $k_{3}$ forms a cluster in line with the maximum compressional stress, whereas $k_{1}$ and $k_{2}$ form a girdle in the plane of extension. Figure adapted from Ankerstjerne et al. (2015).

\section{FIGURE 5.}

Aerial photograph (from 2014) of a portion of the Múlajökull forefield, with sample site locations indicated. The 23 sites on drumlins are indicated with white dots and site numbers, whereas the five sites in interdrumlin areas are indicated with grey dots and site numbers. Drumlins are outlined.

\section{FIGURE 6.}

Sampling till for AMS analysis by inserting plastic boxes into (a) a horizontal platform excavated in till (inset: stream cut where AMS samples were collected from a vertical profile of 
four horizontal platforms, indicated by white dotted lines, excavated at depths of up to $4.1 \mathrm{~m}$ below the drumlin surface) and (b) a vertical surface. Both sites were cleared of colluvium to access in situ till.

\section{FIGURE 7.}

Average elevations of ten profiles from ten $100 \mathrm{~m}$-wide swaths, normalized to the elevation and location where they cross the upglacier side of the 1992 surge moraine. Each swath begins at or near the ice margin and ends either where LiDAR coverage ends or at the most distal (Little Ice Age) moraine (see Fig. 1). Thus, the leftmost point on each elevation profile corresponds with the location of the modern ice margin. Distances along the swath profile are relative to the 1992 surge moraine, with negative numbers indicating increasing proximity to the glacier margin and positive numbers indicating increasing proximity to the Little Ice Age moraine.

\section{FIGURE 8.}

Orientations of principal magnetic susceptibilities of the Múlajökull till subjected to shear strains of $\sim 31$ (left) and $\sim 37$ (right) in ring-shear experiments, based on the AMS of 73 and 62 intact samples, respectively. Orientations of principal susceptibility $k_{l}$ are represented by solid circles (with their $V_{1}$ orientation shown by large solid circle), $k_{2}$ by squares (their $V_{1}$ by large square), and $k_{3}$ by crosses (their $V_{l}$ by large cross). Sense of shear is indicated by arrows. Upglacier plunges of $k_{1}$-based $V_{l}$ orientations are $15^{\circ}$ (left) and $24^{\circ}$ (right). Fabric strengths based on orientations of $k_{l}$ are $S_{1}=0.77$ (left) and $S_{1}=0.74$ (right). 


\section{FIGURE 9.}

Vertical profile of AMS fabrics from Site 1 (Fig. 5). The approximate depth from the drumlin surface to the sample platform is listed to the left of each fabric, along with the corresponding till units described in Johnson et al. (2010) (J2010) and Benediktsson et al. (2016) (B2016). The fabric strength based on $k_{l}$ orientations, given by the $S_{l}$ eigenvalue, is shown to the right of each fabric. The $V_{l}$ eigenvectors of the $k_{l}$ orientations have been projected onto the shear plane (see section 4.2.1).

\section{FIGURE 10.}

Rose diagrams showing the direction of shearing based on AMS and clast fabrics, bootstrapped and plotted with respect to a common drumlin orientation (interdrumlin fabrics were reoriented using the average orientation of the two drumlins adjacent to them). Bootstrapped drumlin fabrics are separated by drumlin quadrant. The red arrows on rose diagrams show the average azimuth of the drumlin surface contours, also plotted with respect to a common drumlin orientation, at each of the sites where samples for AMS fabrics represented in the diagrams were collected (plus or minus one standard deviation shown with dashed arrows). Site ground-surface attitudes are reported in Table B-1 of the supplementary material. Rose diagrams of clast fabrics indicate clast long-axis orientations, rather than sediment shearing azimuths. Unlike the triaxial AMS fabrics, the true shearing azimuth cannot be derived from clast fabric data. Attitudes of drumlin surfaces were not recorded for clast fabrics. 


\section{FIGURE 11.}

Equal-area, lower-hemisphere stereonet projections of bootstrapped poles to shear planes derived from AMS data for (a) the east (blue) and west (red) sides of the drumlin (the solid circle shows the average plunge of poles to drumlin surfaces where AMS samples were collected, plus one standard deviation, indicated by the black dashed circle) and (b) interdrumlin areas. Note that stereonet plots in this figure are zoomed in so that they span plunges of $\sim 45-90^{\circ}$; inset plots show entire area $\left(0-90^{\circ}\right)$

\section{FIGURE 12.}

Common-means testing of the Cartesian components (Tauxe et al., 2015) of the poles to shear planes from the east (blue) and west (red) sides of the drumlins. In these graphs, the cumulative distribution of each dataset is shown relative to a common mean of the combined datasets (set at 0 on the horizontal axis). Vertical lines show $95 \%$ confidence intervals for the mean of each individual dataset. These tests indicate that poles to shear planes on either side of the drumlin long axis are similar in the extent of their N-S and in their Z (vertical) components (top and bottom graphs, respectively) but significantly different in their E-W component (middle graph).

\section{FIGURE 13.}

Striation orientations on bullet boulders (red arrowheads). Drumlin shapes are indicated in gray beneath the contours, and the 2013 ice margin is noted in blue. The contour interval is $1 \mathrm{~m}$. It at lower right shows the maps locations. 
FIGURE 14.

Virgin compression curve, determined from five consolidation tests on till (Table 2), with 95\% confidence interval (dashed line). Equation: $\rho_{b}=86.308 \ln \sigma^{\prime}+1319.6$, with $R^{2}=0.81548$. Each consolidation test on an intact till sample yielded two data points: one corresponding to the effective stress at an initial void ratio and one to the effective stress at a void ratio $60 \%$ smaller than the initial void ratio.

\section{FIGURE 15.}

Grain-size distributions of samples from drumlins (15 sites on five drumlins) and interdrumlin areas (five sites from three interdrumlin areas). Data are shown in percentages of sand (2 mm to 50 microns), coarse silt (50 to 10 microns), fine silt (10 to 2 microns), and clay (<2 microns), by mass. Grain size was measured by sieving and pipette analysis.. Two-tailed t-tests for each class size indicate no significant difference $(\mathrm{p}>0.10)$ in the textures of tills from drumlin and interdrumlin areas. 


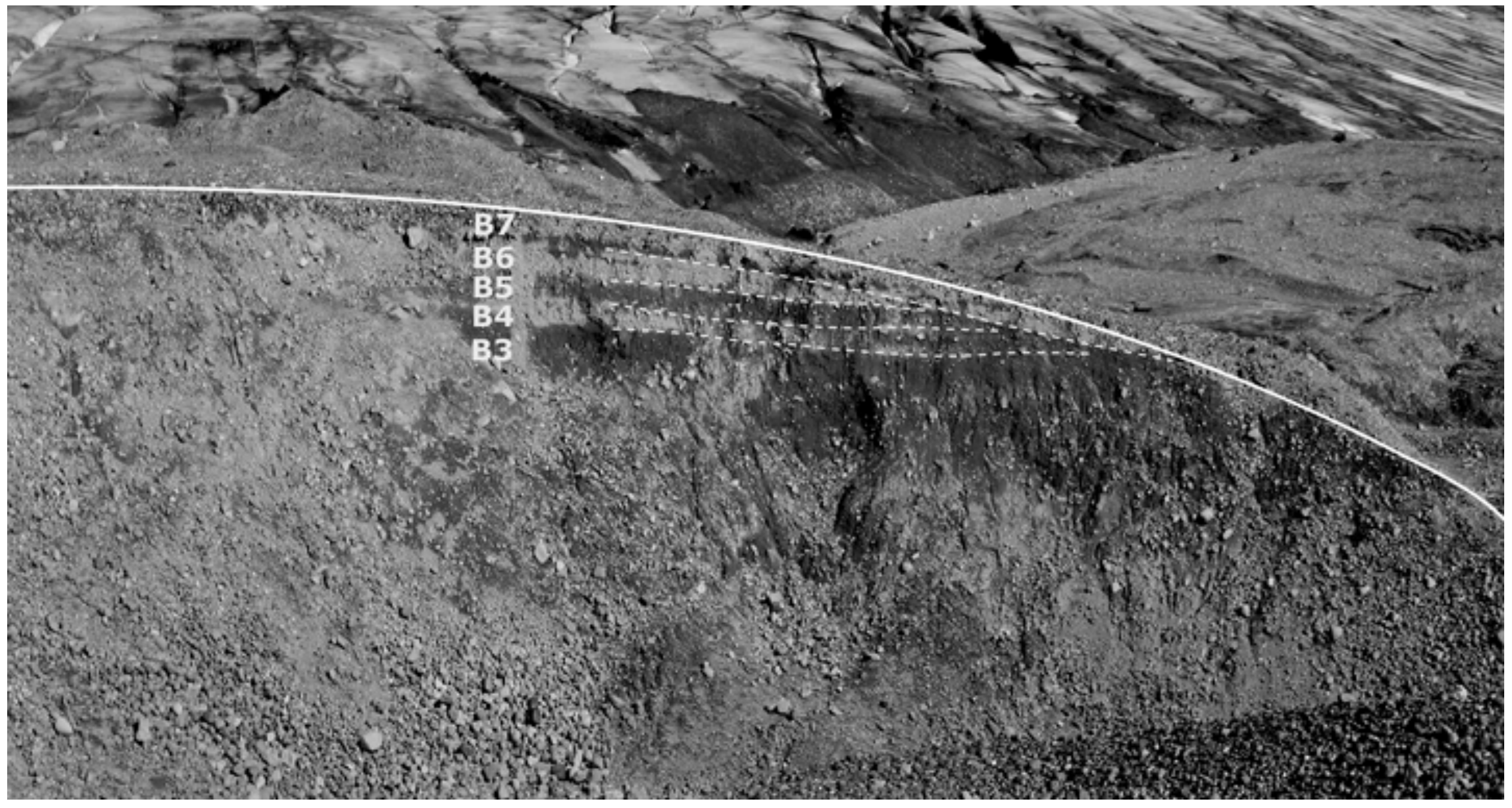


Fjgure 4

(a)

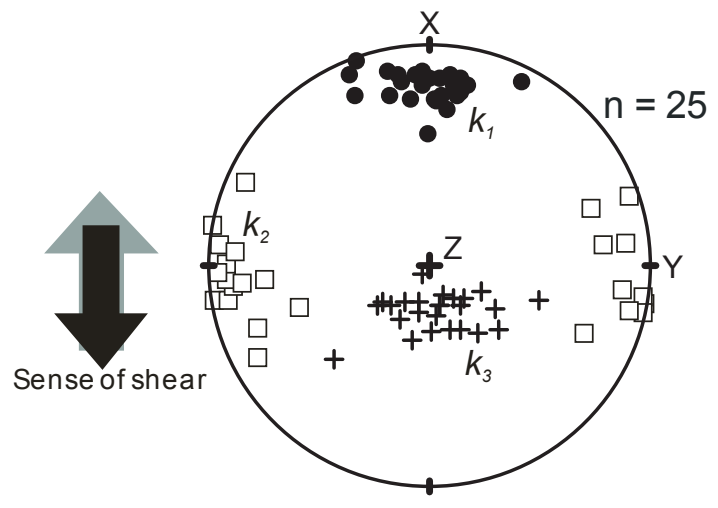

Simple shear

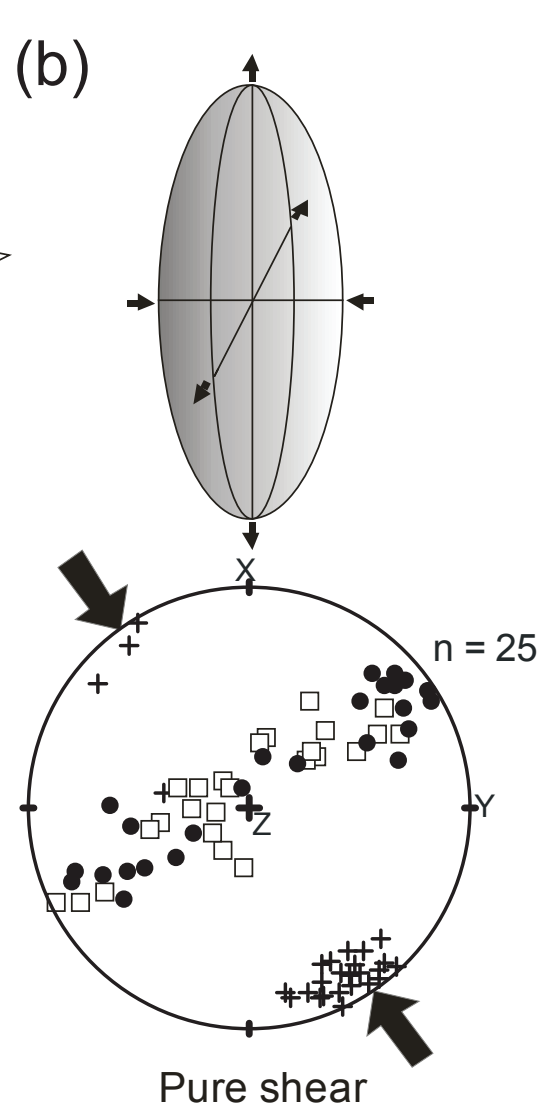




\section{Sitee 1 AMS fabrics}

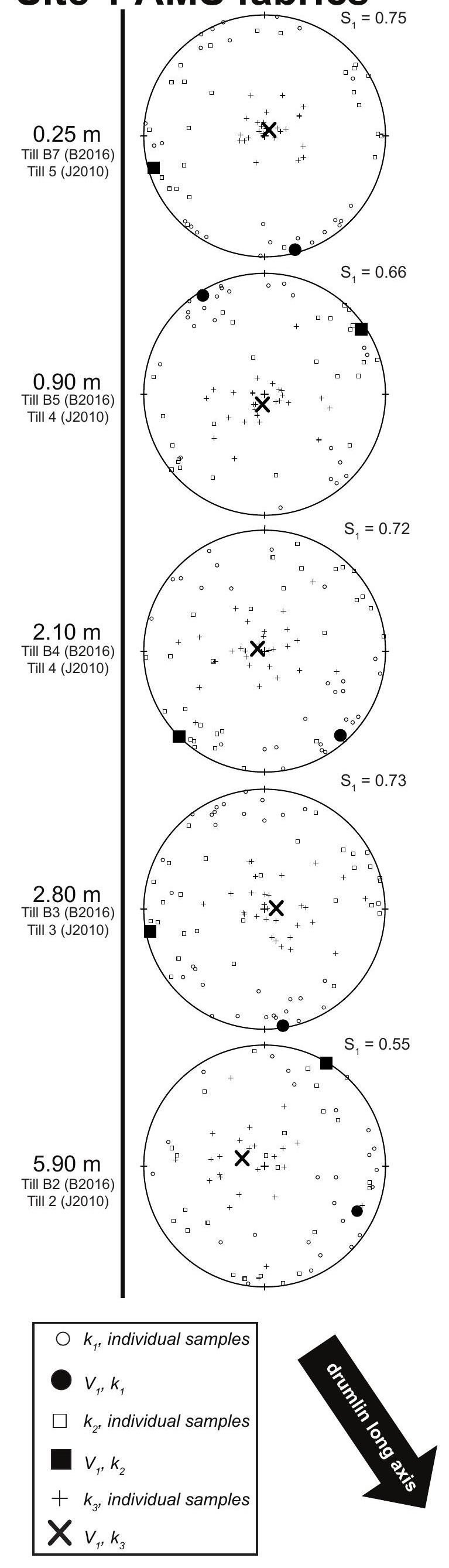


(agure 11 Drumlin fabrics

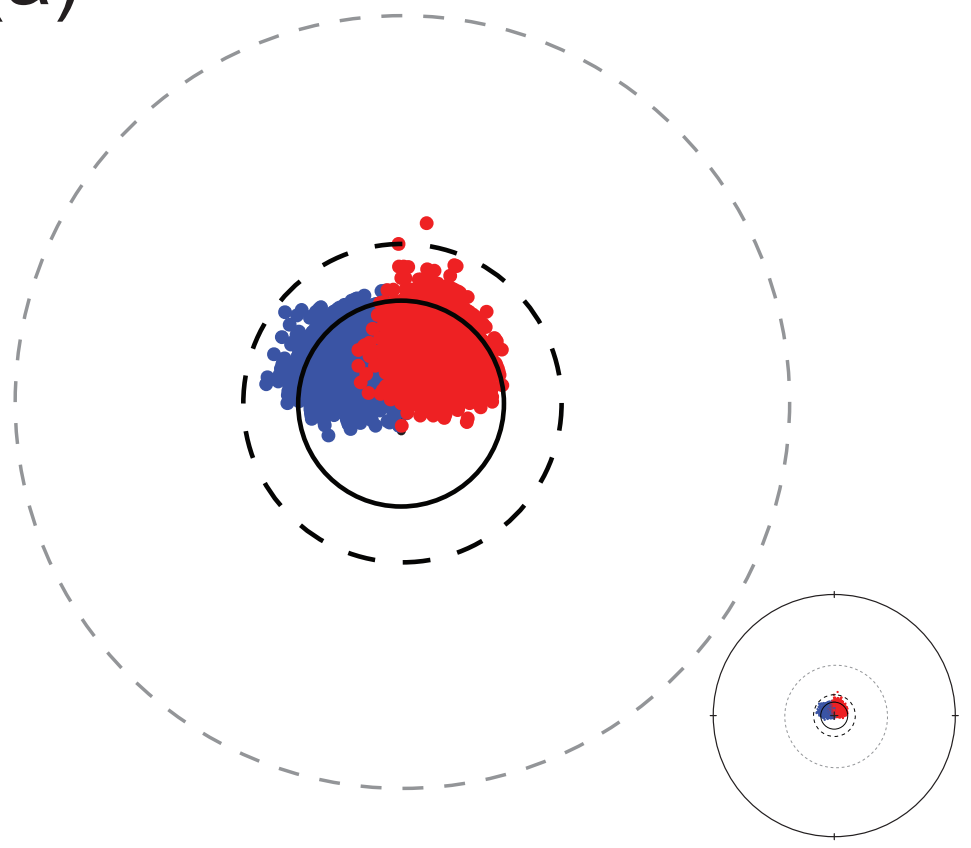

(b) Interdrumlin fabrics 


\section{Figure 12}
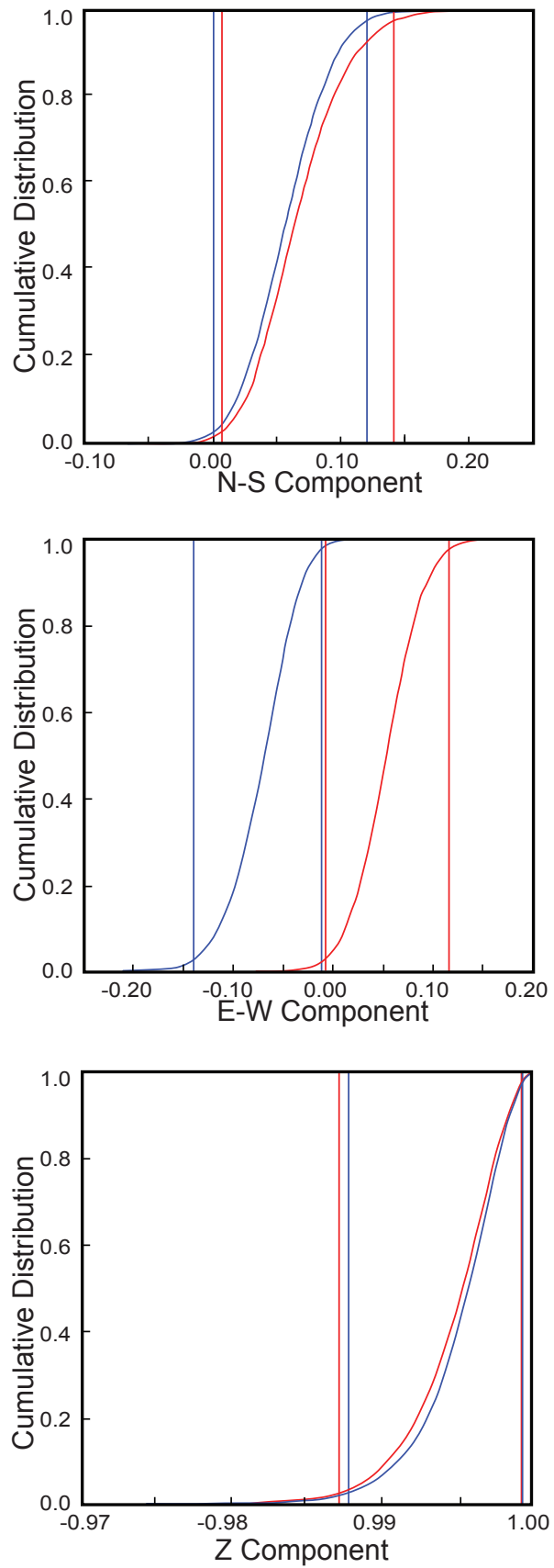


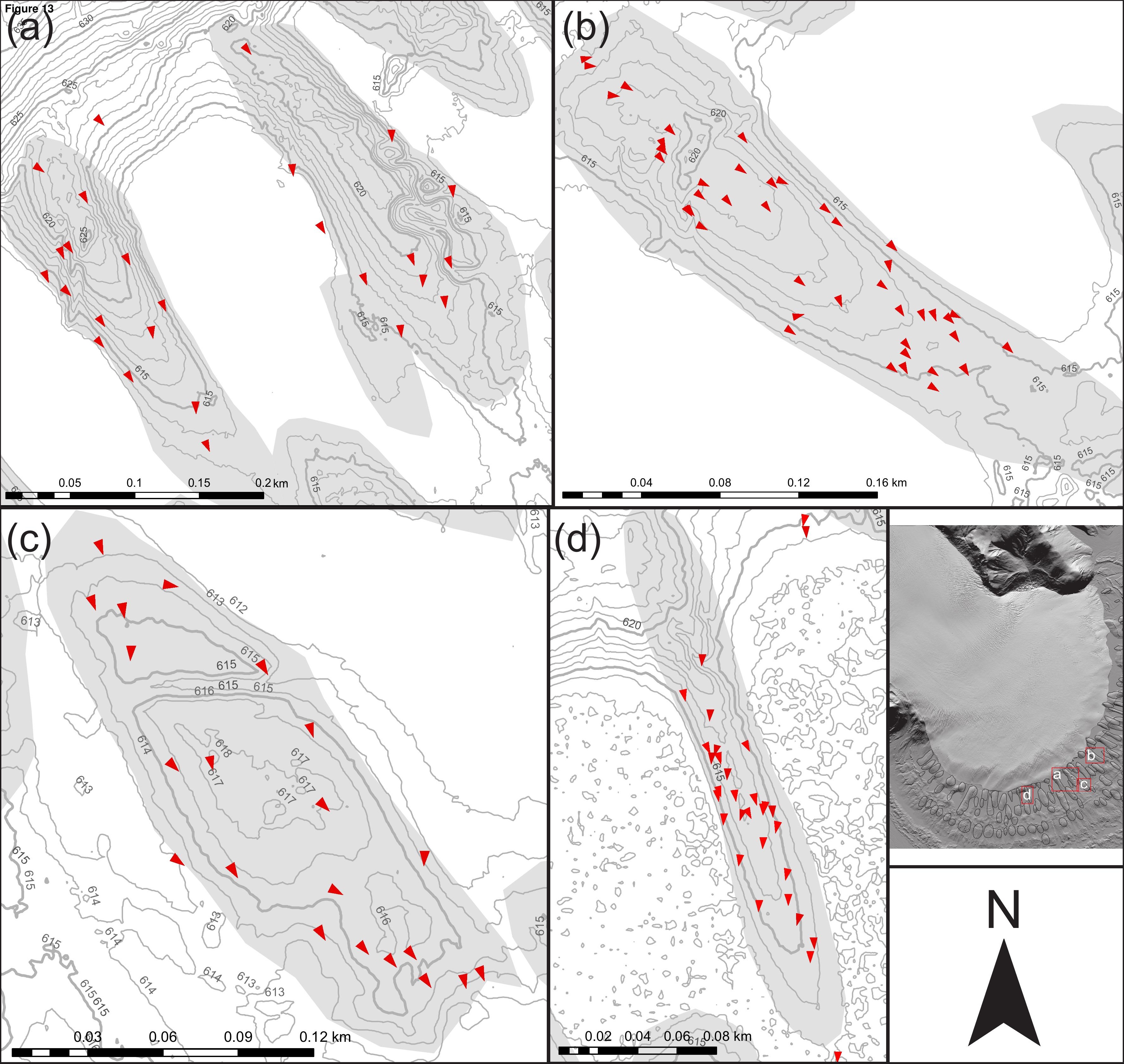


Figure 14

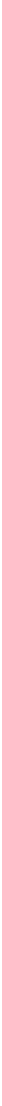




\section{Figure 15}

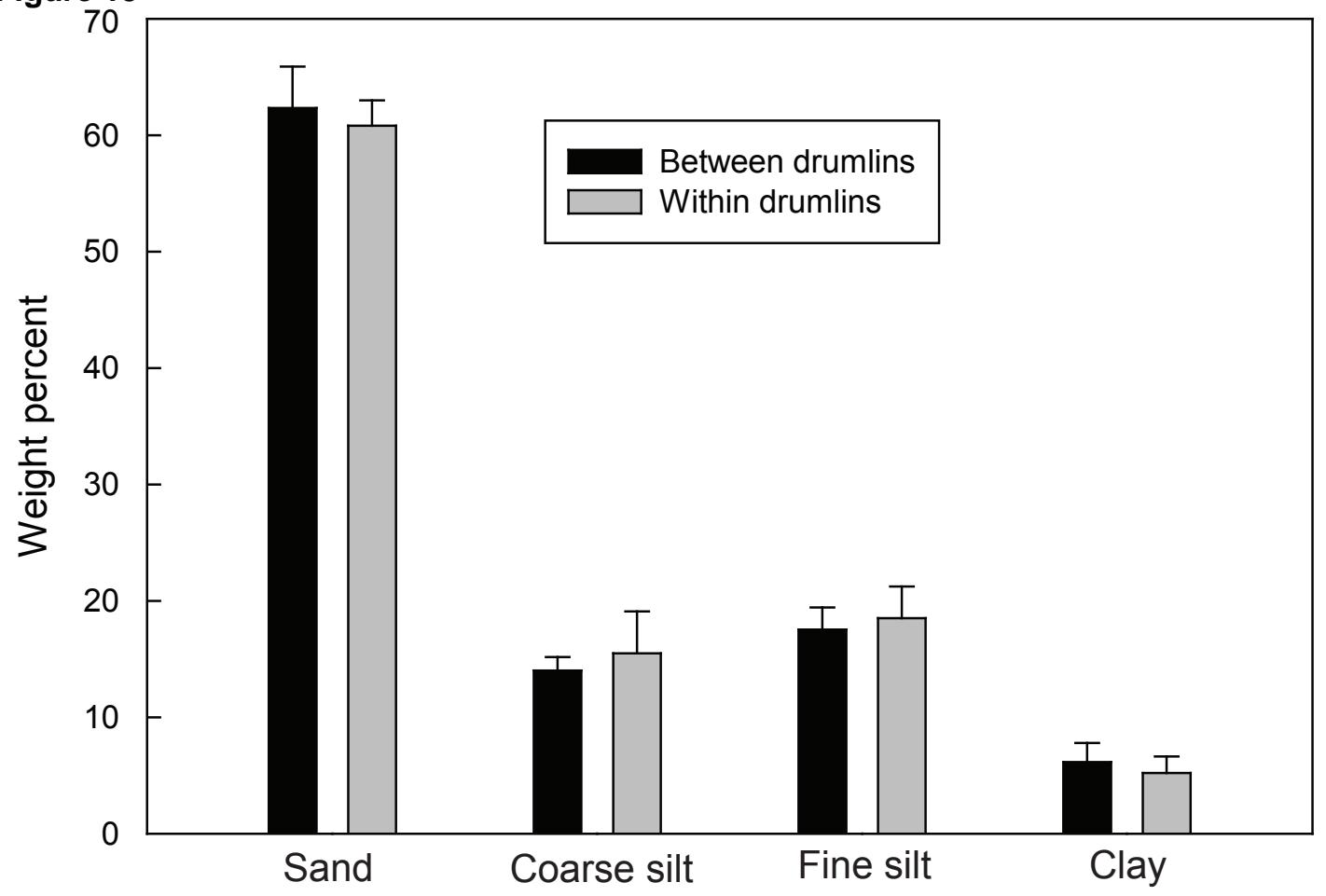

Grain size 